This is an Accepted Manuscript of an article published by Taylor \& Francis in New Genetics and Society on 30 Jun 2016, available online:

http://www.tandfonline.com/doi/full/10.1080/14636778.2016.1197109

\title{
Crossing disciplinary lines: reconciling social and genomic perspectives on the histories and legacies of the transatlantic trade in enslaved Africans
}

\author{
Sarah $\mathrm{Abel}^{\mathrm{a}, \mathrm{b}^{*}}$ and Marcela Sandoval-Velasco ${ }^{\mathrm{c}}$ \\ ${ }^{a}$ Centre international de recherches sur les esclavages, Paris, France; ${ }^{b}$ Ecole des hautes \\ études en sciences sociales, Paris, France; ${ }^{c}$ Centre for GeoGenetics, Natural History \\ Museum of Denmark, Copenhagen, Denmark
}

(Received 29 April 2016; final version received 31 May 2016)

\begin{abstract}
Over the past two decades, advances in the field of genomics have presented new opportunities to shed light upon the origins of enslaved Africans and their contemporary descendants. While this possibility has caused enthusiasm among members of the public, it has provoked contention within the academic sphere. This paper represents an attempt to reconcile these opposing disciplinary divisions, by examining, explaining, and discussing the processes involved in the production of genetic "ancestry" estimates, in order to moderate the aura of absolute "truth" that is often associated with such techniques. Our discussion focuses on two case studies the academic use of ancient DNA analyses to estimate the geographic origins of historically enslaved individuals, and the commercialization of DNA "ancestry" testing techniques aimed at African-American roots-seekers - and draws upon recent ethnographic data relating to the experiences of test creators and test-takers, in order to contribute to this debate.
\end{abstract}

Keywords: Transatlantic slave trade; DNA ancestry testing; history; genomics

During a 2013 interdisciplinary conference in Copenhagen on the topic of transatlantic slavery in Scandinavia, ${ }^{1}$ the cordial atmosphere was briefly ruptured by a heated exchange over the use of genetics in research into the history of the transatlantic trade in enslaved Africans. The protagonists of the debate were historians, geneticists, archaeologists and anthropologists, among others, and the dispute revolved around the question of how, and to what extent genetic technologies could shed light on the identities and geographic origins of individuals displaced by enslavement and the Middle Passage. On the one side, a group of "genetic skeptics" highlighted concerns about how molecular data might be used to create deterministic classifications of human groups, and questioned the validity of applying biological

* Corresponding author. Email: sarah@eurotast.eu 
data to questions of social identity. On the other side, a group of "genetic advocates" drew attention to the rigor and precision of molecular studies, suggesting that genetic analyses were capable of providing insights of a heretofore unparalleled resolution into the history of slavery. Eventually, the discussion was brought to a truce; the original question, however, was left standing, with no one able to propose a middle way to bridge these opposing theoretical stances.

The episode in Copenhagen is but one example of a recurring debate over the scope of genetic studies to cast light upon histories that have long been suppressed by trauma, displacement, and silence. The discussion has proved particularly polemical for research into the origins of the African diaspora, a field that has traditionally faced considerable methodological challenges in its attempts to recover the individual identities of captive Africans, due to its heavy reliance on historical records that habitually omitted the personal details of enslaved individuals. Over the past two decades, genetic analyses have offered the main source of new information on the demographic impact of the transatlantic trade, using large-scale population studies to provide a molecular perspective on the origins and scale of enforced migratory flows between Africa, the Americas, and Europe (Jackson and Borgelin 2010). In addition, since the early 2000s, personalized DNA "ancestry" testing products have been commercially and publicly promoted as a means for African Americans to symbolically "reverse the Middle Passage", by discovering their inherited genetic links to contemporary groups in West Africa (Gates Jr. 2009, 10). While direct-toconsumer (DTC) genetic "ancestry"2 testing companies continue to gain popularity among American roots-seekers, the research community remains divided at the notion of placing genetics at the forefront of the search for historical transatlantic identities (Rotimi 2003; Bolnick et al. 2007; Jackson and McDonald 2008; Bandelt et al. 2008; Dade et al. 2013).

What is at the root of this conflict? The debate, broadly split along disciplinary lines between social and natural scientists, is not merely about methodological concerns. In interdisciplinary discussions of current approaches to studying the transatlantic trade and its legacies, researchers are frequently faced with reminders of how scientists and scholars have been instrumental in perpetuating social injustices in the past. The field of human genetics, for instance, is haunted by its early affiliation to the eugenics movement; research in physical and cultural anthropology was instrumental during the colonial era in constructing scientific "racial" hierarchies and legitimating European control over non-White populations; ${ }^{3}$ and until the second half of the twentieth century, published historical accounts focused overwhelmingly on Eurocentric visions of world history. In the aftermath of World War II, during decolonization and the Civil Rights movement, researchers proposed drastic theoretical and methodological changes in an effort to weed out pernicious practices in their own disciplines. The new field of human population genetics, founded in the $1950 \mathrm{~s}$, positioned itself in the vanguard of research into human "diversity" as it sought for more objective, precise ways to measure and understand biological variation, moving progressively towards mass quantitative analyses on a molecular scale (Dobzhansky 1950; Reardon 2005). Similarly, physical anthropologists rejected 
deterministic "racial" typologies, refocusing their inquiries instead upon processes of human evolution (Montagu 1945; Washburn 1951). In contrast to the natural sciences' focus on increased objectivity and scientific precision, the epistemological shift in the social sciences has been oriented towards a rejection of the existence of absolute truths, and an interpretation of socio-cultural behaviors and beliefs - such as concepts of "race" and "ethnicity" - as the product of local and historical systems of knowledge and power (Bouvier 1997; Foucault 2003, 65-86). Alongside this trend, historians of slavery in the Americas have challenged traditional Eurocentric historiographies by placing the voices and experiences of Black individuals at the core of their analyses.

These profound changes in perspective have been accompanied by the active commitment of many researchers to upholding particular ethical and political stances. For studies into the social and biological impacts of the transatlantic trade, this implies a dedication to anti-racist standpoints by challenging traditional taxonomies of "race"; eschewing cultural and biological essentialisms; seeking dynamic, nuanced perspectives on the past; and highlighting the lived experiences of enslaved Africans as historical, social and biological actors. At the same time, these approaches are informed by public engagement with African-descendant communities, allowing researchers to direct their goals towards the needs and interests of the intended beneficiaries of their work. For example, in the 1990s, scholars from the New York African Burial Ground project set a precedent by tailoring their research aims towards the local descendant community's manifest interest in discovering the individual names, cultural identities and geographic origins of African captives displaced by the transatlantic trade. ${ }^{4}$ Interpreting these demands for knowledge as being rooted in "a desire by members of the descendant community for a detailed understanding of the African cultural backgrounds, and, therefore, the basic humanity of those who were enslaved" (Mack and Blakey 2004, 14), the project's coordinators chose to make a range of bioarchaeological approaches - including some nascent genetic testing techniques - central to their efforts to uncover information about the lives and identities of the Burial Ground population.

In an era in which human identities are widely acknowledged to be fluid, multifaceted, and rooted more in social context and experience than in biology (to paraphrase Simone de Beauvoir, upon what we become rather than what we are), the idea of appealing to genetic techniques as a source of "ethnic" knowledge with regards to living and historic Middle Passage survivors can, on the surface, seem paradoxical - if not retrograde. On the other hand, as numerous scientists and members of the African American community have argued in recent years, the recourse to such biotechnologies can be viewed as justifiable when taking into account the scarcity of traditional sources of historical data relating to the lives and experiences of captive Africans and their American descendants (Blakey 2001; Winston and Kittles 2005; Gates Jr. 2009; Jackson and Borgelin 2010). In this light, it is precisely the reputation of genetics as an "exact" or "hard" science that forms the basis of its appeal: the idea that, even after generations of silence following the enforced erasure of African "ethnic" knowledge and family structures, some elements 
of those lost identities can still be recovered from within our very genetic material. Yet, at the very same time, it is the acclaimed potential of genetic techniques to unveil absolute "truths" that has inspired skepticism and unease among many social scientists.

This article is the product of extensive and on-going discussions between the authors: one, a social anthropologist who has studied closely the scientific development and current uses of genetic "ancestry" technologies by members of the public; the other, a molecular biologist with experience of implementing these technologies in the context of ancient DNA (aDNA) ${ }^{5}$ studies relating to the history and archaeology of the transatlantic trade in enslaved Africans. In it, we draw upon our respective research experiences to scrutinize the processes involved in the production of genetic "ancestry" estimates relating to the origins of enslaved Africans and their descendants, with the aim of clarifying and moderating the aura of absolute precision and "truth" that is often associated with the results of such techniques. Our examination will take into account both methodological factors (for instance, weaknesses and caveats that are inherent to the process of genetic "ancestry" analysis) and epistemological issues, focusing significantly on the differences between how such data are generated, interpreted, and presented to the public in the context of academic research and commercial "ancestry" testing, respectively.

Our paper is organized in two parts. The first takes an in-depth look at how genetic "ancestry" data are generated and analyzed in academic research settings, and is based upon Sandoval-Velasco's first-hand experiences working on several aDNA studies within the framework of the EUROTAST network. ${ }^{6}$ The section begins with a brief overview of the history and development of genetic "ancestry" testing technologies and approaches, leading into a more detailed outline of the first instance in which such techniques were applied to the study of individuals and populations displaced by the transatlantic trade, in the New York African Burial Ground research project. Here, we explore some of the methodological issues that hindered the production of genetic "ancestry" data relating to the Burial Ground population, before turning to the case of a recent study into the skeletal remains of three individuals unearthed in Sint Maarten in 2010, in order to consider the extent to which these constraints have been resolved by the introduction of new experimental standards and technologies in the past two decades. In particular, we highlight the ways in which scientists deal with some of the epistemological uncertainties raised by the handling of "ethnic" and population labels in the course of these analyses, and in the interpretation of their results.

The second part looks at how similar dilemmas are managed in the construction of commercial "ancestry" tests, by drawing upon the example of African Ancestry, a DTC genetic company established in 2003 by Rick Kittles, who was one of the geneticists involved in the African Burial Ground research project. Our case study is constructed using ethnographic data gathered by Abel between 2013 and 2014, including interviews with scientists and scholars involved in the production and interpretation of modern DNA "ancestry" data destined for private consumers, in affiliation with African Ancestry, and with alternative commercial and non-for-profit 
projects. In our analysis we examine and evaluate the efforts of scientists and scholars to balance their own standards of precision and "truthfulness" against commercial interests, as they develop tests that aim to respond to customers' desires for a specific "ethnic" identity, without sacrificing certain criteria of historical accuracy and scientific robustness. We finish by offering an example of one testtaker's experiences, using this as a lens for exploring the extent to which test creators' efforts to tailor their products to the needs and desires of African American clients correspond to the ways in which genetic "ancestry" data are currently being used by members of the public.

\section{Estimating the individual origins of enslaved Africans: advances and uncertainties}

Since the 1990s, just under two hundred years after the abolition of the British slave trade, studies in molecular biology and population genetics have offered increasingly detailed insights into the long-term genomic impacts of the transatlantic slave trade upon modern-day societies throughout the Atlantic World. These studies are the continuation of decades of prior research, which had already offer glimpses of the potential of genetic data to reveal new clues about human origins and migrations. From the early twentieth century, geneticists sought to explain the hereditary mechanisms responsible for the physical variations they had observed within different species, including humans (T. H. Morgan 1910). By the mid-century, studies of the incidence of particular blood types, serum proteins and enzymes (socalled "classical markers") among different human "populations" had become commonplace, as a means of understanding their respective evolutionary trajectories and underlying genetic diversity (Allan 1963; Lewontin 1972; Cavalli-Sforza 1997). Between the late 1980s and 1990s, scientific activity shifted from the indirect study of human genetic diversity through the observation of gene action, to the direct analysis of sequence variations within specific segments of the genome. A notable breakthrough in this respect was a study by Cann, Stoneking and Wilson (1987), in which a comparison of mitochondrial DNA (mtDNA) ${ }^{8}$ sequences found among inhabitants of different world regions was used to provide what is now recognized as the first conclusive evidence that Homo sapiens have a common origin in Africa.

It was less than a decade after the publication of Cann et al.'s study that mtDNA analyses were used for the first time to investigate the origins of human individuals displaced by the transatlantic trade in enslaved Africans. This innovative research attempt arose in the context of the New York African Burial Ground project, which was led by an interdisciplinary group of scholars from Howard University, Washington DC. Historical records indicate that the site, located in the middle of downtown New York city, was originally used as a cemetery for Blacks and outcast Whites, who were refused the right to burial in churchyards, from the late seventeenth century until 1794 (Parker Pearson 1999, 178). Between 1990 and 1992, 419 skeletons were recovered through archaeological excavations, amounting to around $3 \%$ of the total population estimated to be interred there (Blakey 2009, 10). The 
research methodology developed by the team at Howard - who aimed to shed light upon the geographic and cultural origins and physical quality of life of the Burial Ground population, as well as the biocultural transformations and strategies of resistance undertaken by these individuals during their lifetimes - initially envisioned that studies would be organized around five disciplinary axes: skeletal biology, history, archaeology, genetics and chemistry. However, the discontinuation of General Services Administration (GSA) funds earmarked for DNA, bone chemistry, and cellular analyses meant that, beyond the completion of an initial cohort of pilot studies, the project's genetic and chemical research plans were ultimately set aside (Blakey 2009, 13, 15-16).

Despite these drawbacks, the New York African Burial Ground research project can be seen as a pioneer in having proposed the usage of ancient DNA analysis as part of its methodology, at a time when such techniques were viewed with skepticism by certain sectors of the academic community, including the project's financial reviewers (Blakey 2009, 17). While the team of molecular biologists working on the project initially intended to carry out a range of genetic tests, including mtDNA, Y-chromosome (Y-Chr), ${ }^{9}$ and autosomal DNA analyses, ${ }^{10}$ funding limitations, as well as methodological and analytical constraints, resulted in the impossibility of fulfilling these original research goals (Jackson et al. 2009, 92). Nevertheless, the Burial Ground project's final report did include the results of mtDNA analyses conducted upon forty-eight of the disinterred individuals, through a series of studies conducted between 1995 and 1999. The basic methodology of these tests consisted of retrieving mitochondrial genomic material from samples of bone matter, tissue and hair; amplifying ${ }^{11}$ and sequencing DNA fragments from the HyperVariable Region I (HVR-I); ${ }^{12}$ and finally comparing these informative sequences against a published reference dataset comprising 1,800 mtDNA sequences from contemporary human populations around the world. On the basis of these comparisons, the researchers found that forty-five of the skeletal remains could be linked to three mtDNA haplogroups that are currently found in high frequencies among populations inhabiting West and West Central Africa (L1, L2, and L3), while the remaining three sequences found no corresponding matches in the genetic reference database being used by the team (Jackson et al. 2009, 88-89).

Although the outcomes of the mtDNA analyses offered further confirmation of the Burial Ground population's African origins, as suggested by the historical record, a number of limitations to the experimental approach prevented the team from drawing more specific conclusions regarding the individuals' likely regional or population origins. A key drawback identified in the report was the lack of a complete reference database of the contemporary and archaic genetic diversity found among African populations. For many years now, population geneticists have struggled with the question of what can be considered a "representative" sample of human diversity. ${ }^{13}$ In recent decades empirical studies have consistently indicated that human genetic variation is generally distributed in broad clinal structures, which do not necessarily correspond to modern "ethnic", national, or linguistic frontiers (Rosser et al. 2000; Serre and Pääbo 2004; Cavalli-Sforza 2005). However, in the 
context of genetic "ancestry" studies, it is hoped that by uncovering the existence of relatively rare genetic variants, which are limited to populations currently inhabiting more restricted geographic areas, geneticists can narrow their estimates regarding the biogeographical origins of those particular genomic sequences. Moreover, the chances of gaining a more complete view of the overall genetic diversity that currently exists among human populations are likely to be greatly increased by the use of reference databases containing large sample sizes, and representing a more or less even sample coverage of populations of interest, as defined by the study's particular aims. $^{14}$

In the case of the African Burial Ground study, out of the 1,800 mtDNA sequences in the reference database used, 849 corresponded to African individuals, with 520 of these samples having been collected from individuals currently living in Benin, Burkina Faso, Cameroon, Central African Republic, Guinea, Mali, Morocco, Niger, Nigeria, Senegal, and Sierra Leone. The database did not, on the other hand, include any sequences from certain other countries known to have had historic slave trading links with North American territories, such as Ghana, Gabon, Angola, Congo or Liberia - from which at least some of the Burial Ground's population were likely to have originated, and which therefore constituted regions and populations of interest for the study. In the discussion of their study, the researchers therefore raised their concerns that the patchiness of genetic sampling across the West and West Central African region may have lessened the possibility of reliably linking the studied individuals to more localized geographic origins, or to particular "macroethnic" groups (Jackson et al. 2009, 89). ${ }^{15}$

The researchers were also hampered by practical issues, of which perhaps the most challenging was the limited possibility of retrieving enough DNA fragments of a sufficient length to conduct the process of amplification, which was key to sequencing. Contrary to the DNA found in living organisms, the DNA extracted from ancient samples tends to be found in varying states of decay and fragmentation, given the processes of decomposition that occur after death. For this reason, the researchers took the pragmatic decision to focus upon mtDNA samples, given that the high quantity of mitochondria present in each of the body's cells (in relation to nuclear DNA, of which only one copy exists per cell) increased the chances of recovering longer and more intact fragments of genetic material. Consequently, however, no nuclear sequences were recovered through the original Burial Ground studies, meaning that their results necessarily concentrated upon just one area of the human genome, the mtDNA HVR-I, which is inherited matrilineally, and thus does not reflect paternal genomic contributions, making up approximately $0.001 \%$ of an individual's entire genomic material. Added to this was the ever-present risk of sample contamination by foreign DNA (e.g. including micro-organisms, flora and fauna from the burial context; sample handling by researchers involved in the excavation or laboratory investigations, etc.), which threatened to distort the results of the genetic analyses.

In the past fifteen years since the Burial Ground studies were carried out, the field of human molecular biology has been revolutionized by methodological, 
technological, and analytical innovations. Rapid technological developments, including the invention of automated DNA sequencing, ${ }^{16}$ gave rise to the disciplinary shift from genetics - the study of genes, defined as specific, delimited sequences of DNA encoding a particular product or action - to genomics - the study of the entire genome including all coding and non-coding genes and regulatory sequences across the twenty-three pairs of chromosomes. Following the sequencing of the complete human genome in 2001 (IHGSC 2001; Venter et al. 2001), the compilation of global genomic reference databases through worldwide sampling projects paved the way for identifying and cataloging population-specific variants affecting health and disease, as well as individual responses to medications and environmental factors (e.g. The International HapMap Consortium 2003; Via, Gignoux, and Burchard 2010). ${ }^{17}$ Population geneticists were beginning to gain a more detailed overview of global genomic variation by identifying single nucleotide polymorphisms (SNPs) - base pairs found at different positions on the genome, both in and outside of known functional genes, that are known to vary between individuals and populations (e.g. Stoneking and Soodyall 1996; Barbujani et al. 1997; Shriver et al. 1997; Hammer et al. 1997; Jorde et al. 2000; Jobling and Tyler-Smith 2003). ${ }^{18}$ Population structure studies made use of statistical methods to detect patterns among genomic data collected from human groups all over the world (e.g. Rosenberg et al. 2002; Novembre et al. 2008; Bryc et al. 2010), and the resulting clusters of data provided researchers with a means of inferring the relative similarity or disparateness of genotypes from different parts of the globe. In turn, these approaches have been hailed as offering new promise for the introduction of ever more precise genetic "ancestry" estimation methodologies (e.g. Callaway 2012; Elhaik et al. 2014).

The area of aDNA studies has benefited significantly from these recent advances, notably by adopting, developing, and modifying molecular biological techniques in order to establish a specific line of research, focused principally upon maximizing DNA retrieval from ancient and historical samples. In particular, the introduction of high-throughput sequencing (HTS) technologies, ${ }^{19}$ allowed the shift from recovering just a few short DNA fragments from a specimen (i.e. from the mitochondrial genome and Y-chromosome), to studying millions of smaller fragments and, in some exceptional cases (e.g. Rasmussen et al. 2010, 2011; Keller et al. 2012), even piecing together complete ancient genomes, using genome-wide data. Simultaneously, the development of new algorithms made it possible for the first time to compare relatively low coverage ancient DNA samples (e.g. $0.1 \mathrm{x}$ genome coverage) with higher quality modern datasets - and, in doing so, to make robust inferences regarding potential ancestral affinities between ancient and modern samples. In one stroke, large amounts of reference data from modern panels of human genetic variation were placed at the disposal of a variety of ancient population genomic studies (Skoglund et al. 2012).

These were some of the key developments that made it possible to extract genome-wide aDNA data from three seventeenth century African captives whose remains were found on the Caribbean island of Sint Maarten, and to use a modern West African population dataset in order to compare and estimate the ethno- 
geographical origins of these individuals (Schroeder et al. 2015). One of the authors of this paper, Sandoval-Velasco, was among the researchers involved in these analyses, and for the remainder of this section we draw upon this example as a case study for examining the extent to which recent advances in the field can be considered to have helped overcome some of the methodological caveats that affected earlier attempts to infer the origins of historic individuals displaced by the transatlantic trade, such as in the case of the New York African Burial Ground. In particular, we highlight some of the methodological and epistemological uncertainties still encountered by researchers in the course of these processes, and describe the strategies they use to try and strengthen the accuracy and robustness of their results.

In March 2010, construction work in the Zoutsteeg area of Philipsburg, Sint Maarten revealed three articulated human skeletons. Initial morphometric assessments indicated that these were the remains of two males and one female aged between 25 and 40 at the moment of death - and the archaeological report noted that artifacts associated with the burials (ceramics, brick and glass fragments, and an almost intact conch shell) firmly suggested that they dated to the mid- to lateseventeenth century, prior to the foundation of the town of Philipsburg in 1735. In addition, dental modification features found on each of the skeletons strongly suggested they were of African ancestry, and the form and date of the burial suggested a slave burial context. Jay Haviser, the lead archaeologist from the dig, and biological anthropologist Hannes Schroeder, who was directing the bioarchaeological analyses, arranged for strontium isotope analyses to be carried out upon tooth samples from the deceased individuals. The results provided further evidence for the African origins of the "Zoutsteeg Three"; however, neither the patterns of dental modification, nor the strontium isotope values could offer any clues to indicate a more specific origin in Africa (Schroeder, Haviser, and Price 2012). In light of this, Schroeder decided to attempt to carry out aDNA analyses on the samples, in the hope of providing narrower estimations of the individuals' geographical origins within Africa.

The tooth samples were subsequently sent to the Centre for GeoGenetics at the University of Copenhagen, where initial attempts at DNA retrieval were frustrated by the low amounts of endogenous DNA recovered. ${ }^{20}$ As in the case of most aDNA studies (see for example Kaestle 2003), the analyses showed that contamination was a dominant issue, given that initial analyses showed that most of the sequencing data $(>95 \%)$ could be attributed to microbial and environmental DNA present in the samples. However, thanks to HTS technologies, even during these early attempts the researchers were able to recover complete mitochondrial genomes and fragments of nuclear DNA with relative ease. A number of tweaks to the aDNA extraction process and to the library preparation methods, ${ }^{21}$ carried out through a process of trial and error over the course of around five years, gradually led to the obtention of sufficiently large amounts of DNA to go ahead with the analyses. Ultimately, it was the introduction of Whole-Genome Enrichment (WGE) methods ${ }^{22}$ in 2013 that constituted the most significant step forward: by "fishing" out the human aDNA 
fragments in the sample and discarding the non-human portions, the team was able to increase the amount of human DNA recovered from the samples sixfold.

Following sequencing, the researchers were able to recover enough low-coverage genome-wide data (corresponding to between $9.5 \%$ and $44.6 \%$ of the full human genome sequence) from the three historical individuals to begin their analysis, which consisted of comparing these sequences against a modern panel of genetic population data. In any study concerned with genetic "ancestry" estimations, the choice of reference panel is key, in that the contents of the database will necessarily define the scope and specificity of the results. Given that the background historical information, as well as the isotope results for the Zoutsteeg Three had indicated an African (and more specifically a West African) origin, human genomicist María Ávila-Arcos, who was heading the computational analysis, decided to opt for a dataset compiled specifically of samples collected from African populations. At the time, the obvious choice was a set of genotype data published in a recent study by Bryc et al. (2010), comprising data collected from 201 individuals from eleven different populations in West Africa (Bamoun, Brong, Bulala, Fang, Hausa, Igbo, Kaba, Kongo, Mada, Yoruba and Xhosa), relating to 294,651 genomic loci (SNPs). Aside from its reasonable coverage of the broad geographic region in which the individuals were thought to have most likely originated, this was one of the few existing datasets to fulfill another important criterion: namely, the reference samples needed to consist of autosomal genotype data (rather than other variation markers such as microsatellites, RFLPs, etc.), in order to be directly comparable to the genome-wide aDNA data under study. In this respect, while the study benefited from a dataset that was more geographically suited to its aims, in comparison to the one used for the Burial Ground analyses, the team nonetheless experienced constraints due to the general scarcity of databases containing genotype data for African populations (see note ${ }^{17}$ ).

Next, in order to determine whether the Zoutsteeg Three showed close affinity to a particular population within the reference panel, the researchers applied Principal Component Analysis (PCA) to the samples. Based on the theory that genomic variation is geographically structured, PCA illustrates and represents this variation visually by reducing the variation present in the genome into two components: PC1 and PC2. Because variation is structured, individuals with relatively similar genotypes tend to group together forming defined clusters. Thus, Ávila-Arcos merged the sequence data for each of the three historic individuals with those of the reference panel genotypes and calculated PC1 and PC2 based on the overlapping sites, corresponding to the intersection of the ancient data with the reference panel. The analyses showed that one of the individuals clustered most closely with samples collected from Bantu-speaking groups in northern Cameroon, whereas the other two clustered with samples from non-Bantu speakers living in present-day Nigeria and Ghana. ${ }^{23}$ These outcomes were eventually cited in the study's conclusions, which stated: "the genetic data suggest that STM1 may have originated among Bantuspeaking groups in northern Cameroon, whereas STM2 and STM3 more likely originated among non-Bantu speakers living in present-day Nigeria and Ghana" (Schroeder et al. 2015, 3671). 
On a technical level, Schroeder et al.'s project represented a considerable scientific achievement: notably, the team managed to extract workable aDNA data from skeletal remains that were found in environmental conditions that were certainly suboptimal for the preservation of genomic material over large periods of time. This methodological advancement therefore left room for optimism regarding the future of aDNA studies upon human remains linked to the transatlantic trade, given that many African burial sites throughout the Americas are to be found in similarly hot and humid climates - for instance, the burial ground of Ruperts Valley in the island of Saint Helena, Chorro de Maita in Cuba, the Cemitério dos Pretos Novos in Rio de Janeiro, etc. (Souza et al. 2012; Sandoval-Velasco et al. 2015; Lawler 2016). Yet, the study also marked a symbolic landmark, in that it demonstrated that aDNA analyses could help directly shed light upon the personal origins of captive and enslaved African individuals, with a degree of regional specificity that was previously thought impossible. ${ }^{24}$ It was this element in particular that was picked up and reported on by not only popular science and archaeology magazines (one of which ranked the study's findings among of the top ten archaeological discoveries of 2015), but also regular online news sites and radio stations in various different languages and countries. ${ }^{25}$ As Fatimah Jackson - a biological anthropologist and the lead researcher in the African Burial Ground studies - remarked in one such article, the study could thus be considered as contributing to the current broader academic and political effort to "honor" the lives of historically enslaved Africans by "allow[ing] their story to be told" (L. Wade 2015).

Since the pioneering African Burial Ground research project, many archaeological studies of sites linked to transatlantic slavery have begun to shift their focus towards uncovering evidence that could shed light upon the "ethnic" affiliations of captive and enslaved Africans, in order to offer more specific inferences about the cultural traditions and worldviews that these individuals brought with them to the Americas (see Mack and Blakey 2004). ${ }^{26}$ Although the Zoutsteeg Three studies were firmly situated within this analytical trend, the Copenhagen team was keen to emphasize the limitations of the inferences that could be drawn about the personal stories or identities of these individuals, based on their genetic information. While some of these caveats relate to the methodological constraints mentioned above, others are epistemological in nature - for instance, how to deal with the fundamentally mutable and subjective nature of "ethnic" identities in the context of an analytical technique that relies upon statistical confidence and unambiguousness in its data sources?

To tackle this question, it is necessary to take a closer look at how human population samples are collected and compiled into the reference panels that form the basis of genetic "ancestry" inferences. ${ }^{27}$ In all cases, genetic sampling expeditions are planned and carried out in conjunction to particular research projects, and it is these initial studies' aims (e.g. medical, historical, forensic, etc.) that are used to define crucial questions, such as which populations will be targeted (e.g. based on disease traits, physical characteristics, geography, nationality, ethnic affiliation, language, or a combination of these factors); who constitutes an "ideal" sample donor; and how many samples will be gathered to represent each population. Once these aims are 
defined and the project has received ethical approval from the relevant authorities, the sampling team approaches their target populations. ${ }^{28}$ During the collection procedure, researchers also gather personal data from each donor to accompany their sample. In the case of population genetics projects, samples are generally tagged with the following information: 1) genealogical details relating to the past three generations (meant to rule out recent migrants to the area, or individuals of "mixed" ancestry); 2) the geographic location of the sample collection (sometimes expressed as GPS coordinates); and 3) "ethnic" labels, which may be based upon the volunteer's selfdesignation (e.g. Bryc et al. 2010), or attributed by the researcher (e.g. Gonçalves et al. 2008), or both. Additional data may also include linguistic markers and particular phenotypic characteristics, if deemed relevant to the study's aims. Finally, each sample is assigned an ID number, in order to protect the anonymity of the donor.

After sample collection the DNA is extracted, and, both before and after genotyping or sequencing, the samples are subjected to exhaustive quality controls and data processing. ${ }^{29}$ In the case of biogeographical population studies, the aim of these procedures is to produce a reference dataset that shows as clearly as possible the patterns of genomic variation within and among the populations studied. For this reason, researchers may remove individuals from the dataset who are highly related, or who display a high degree of admixture with another population - since, depending on the particular scope of these study, these can create statistical "noise" and skew the dataset. They also look out for individuals who appear to have been "mislabeled" - for instance, an individual who has been labeled "Fulani" but clusters more closely to Xhosa samples is considered to be an outlier, and the sample removed from the cohort. Consequently, the resulting panel does not represent a random cross-section of the groups or territories from which the samples were gathered; rather, it consists of a select collection of DNA sequences, chosen for their aptness at reflecting geographic distance, and/or, in some cases, "ethnic" or linguistic boundaries, on a genomic level.

The objective of these measures is to reduce ambiguities regarding the "ethnic" and geographic affiliation of the samples, in an effort to produce a robust reference dataset that will allow clear and precise "ancestry" estimations on the basis of genetic data only. As a result, for pragmatic reasons, this process often means simplifying or excluding certain layers of the nuance and ambiguity that characterize human social identities - for instance, the possibility than an individual speaks numerous languages; that she changes or acquires new "ethnic" affiliations over the course of her life due to travel, marriage, or enforced acculturation; or that her parents are of different geographic origins or cultural affiliations. Indeed, historians of African societies have estimated that many of these scenarios likely applied to individuals living in West Africa during the period of the transatlantic trade, with certain scholars notably emphasizing the "interlocking, overlapping, multiple and alternative" character of collective identities in the pre-colonial period (Southall 2010, 91; Berman 1998). Inevitably, it is beyond the scope of genomic analyses to capture the full, multi-faceted scale of human cultural, linguistic, and social affiliations - and this constitutes the fundamental difference between the concept of "genomic identity", 
which is descriptive, and approximative, and social identities, which are built upon lived, subjective experiences.

In light of these considerations, it is important to emphasize that, whereas technical advancements can help improve the robustness of analyses (for instance, by increasing the amount of genomic material and the number of markers that are examined), and the compilation of more comprehensive modern and archaic population reference databases can improve the chances of making pertinent comparisons, there is a natural limit to the level of accuracy and precision that these techniques can afford. In the case of Schroeder et al.'s aDNA study, this is made obvious by the simple fact that there is no way of verifying what languages the Zoutsteeg Three spoke, and whether they really did live in present-day northern Cameroon, Nigeria or Ghana. Thus, rather than revealing a concrete historical truth, these "genomic identities" are intended to merely provide "an alternative kind of record that can help shed light on long-standing historical questions, in cases where documentary records are scarce or unavailable" (Schroeder et al. 2015, 3671).

In the next section, on the other hand, we turn to a case in which genomic identities are deliberately generated with the aim of informing social identities. Our discussion focuses on the case study of African Ancestry - the first company to target DNA "ancestry" products specifically at the African descendant community, and by now one of the longest-running enterprises in the industry. In what follows, we examine a number of methodological critiques of African Ancestry's tests, made by geneticists and historians involved in rival projects and enterprises, as a means of assessing the moral and political stakes involved in presenting individualized data to members of the public, and the strategies used by test-creators to navigate these issues.

\section{Promises and problems in the African ancestry experience}

For many Americans, the PBS documentary African American Lives (2006), afforded a first point of contact with the concept and practice of genetic "ancestry" testing. Presented by Harvard professor Henry Louis Gates, Jr., the series consciously echoed the format of Alex Haley's celebrated genealogical saga, Roots (1976), following nine African American celebrities (including Gates himself) on a virtual journey through their family trees. Like Haley, the show's research team used documental archives to trace each participant's genealogy back to the earliest American records in which their ancestors were named, generally dating to the mid-nineteenth century. ${ }^{30}$ However, whereas a scrap of oral history guided Haley to trace one branch of his family tree to a village in the Gambia, the participants of African American Lives were linked to their ancestral African homelands by virtue of a DNA test, the results of which were presented to each of them in the final episode of the series.

The disclosure of the "ancestry" test results was carried out in two parts, with each individual first receiving a set of autosomal "ancestry composition" results, expressed as a series of percentages that summarized his or her relative proportions of "African", "European", and "Native American" genomic "ancestry". The show's 
climax, however, came with the revelation of the mtDNA and Y-Chr results, by which each celebrity was linked to a named African "people" and homeland. Viewers were able to watch the process by which a team of geneticists and historians constructed these results, first through the use of a reference database in which all close or exact haplotype matches between the participants and various sampled populations across Africa were identified, and then through the examination of historical data to estimate which of these matches was most likely to correspond to a "true" ancestral connection - or rather, one that likely represented the geographic origins of the individual's ancestors during the era of transatlantic slavery. Finally, viewers accompanied one member of the group, comedian Chris Tucker, on a "homecoming" trip to a village in Angola, where, as Gates speculated in the voiceover, one of his ancestors may have originated. Commenting on his DNA testing experience as part of the documentary, Tucker stated: "There's wisdom in knowing where you're from, and I know now. This is the greatest thing that ever happened to me" (Judd 2006).

Aside from setting a model for the now ritualized emotional responses and follow-up activities that are now routinely associated with genetic "ancestry" testing (Nelson and Hwang 2012), the series provided publicity for African Ancestry, a Washington DC based "ancestry" testing company owned by the molecular biologist Rick Kittles and business entrepreneur Gina Paige, which provided the mtDNA and Y-Chr tests for the show. As sociologist Alondra Nelson has demonstrated in depth in her recent work The Social Life of DNA (2016), the idea for the company originated during Kittles' stint as a researcher at the New York African Burial Ground Project during the late 1990s, where he was recruited to develop genetic methods for estimating the origins of some of the historic individuals disinterred at the site. Through conversations with news reporters and members of the Black community who had closely followed the developments at the Burial Ground, Kittles and his fellow colleagues from Howard University soon became aware of a fervent public interest in these pioneering analyses. According to Nelson, it was Kittles' own experiences as the leader of an Afrocentric student group, and as an amateur genealogist, that inspired him to begin searching for a means to commercialize these techniques, in order to make them available for public use. Nevertheless, other members of the research group mounted a stern opposition to Kittles' plans, and he was forced to leave the African Burial Ground Project in 1999. After a short-lived plan to base his venture at Howard University (Fulwood III 2000; JBHE 2000; Roberts 2011, 232), Kittles left the institution and struck up a partnership with Paige. In 2003, the pair announced the launch of African Ancestry, Inc., and the enterprise finally began to offer its DNA products to the African American public (Nelson 2016, 63-67).

Since the company's establishment, African Ancestry has spearheaded an emotive advertising campaign that emphasizes the feelings of empowerment and joy felt by many clients at being able to claim a genetic connection with a specific African group and country for the first time. The test's benefits are listed in the promotional video featured on the African Ancestry homepage: 
You'll find out what country and possibly even what ethnic group you're a descendant of; define a sense of identity for you and your kids; solidify a true connection to the motherland; $[. .$.$] acquire a new sense of pride; leave behind a legacy; know who you are.$

The idea that African Ancestry can provide customers with a "true" and "authentic" link to Africa is heightened by the formal and ceremonious way in which the results are presented, in the form of a personalized letter from Paige, accompanied by a Certificate of Ancestry that is stamped and signed by Kittles, the company's scientific director. The letter typically includes a read-out of the customer's mtDNA sequence for the HVR-I, or a table listing the specific Y-Chr Short Tandem Repeats (STR) ${ }^{31}$ used to determine their ancestral affiliation to one or more African groups. It also informs customers that the Certificate of Ancestry "authenticates" their paternal or maternal ancestry, and invites them to "display it with pride among other family documents". These touches are clearly meant to attest to the scientificity of the results - not only for the benefit of the customer, who has already demonstrated his or her good faith in the quality of the information provided by the company by paying up to $\$ 300$ for the test, but also in the eyes of third parties. Some African Ancestry testtakers, for instance, claim to carry their certificate around with them daily, as "proof" of their origins; ${ }^{32}$ others liken it to a "birth" certificate, ostensibly marking their spiritual "return" to a pre-slavery identity (Nelson 2016, 102). Clients can also opt to demonstrate their new affiliation by purchasing official African Ancestry T-shirts from the company web store, emblazoned with the name of their country of "origin" and the phrase "KNOW YOUR ROOTS" in the green, gold, and red hues of the PanAfrican colors.

African Ancestry can be considered unique within the context of the DNA "ancestry" testing market, in the extent to which its customers are encouraged to identify with their new genetic appellations. This is in large part down to the skill with which Paige and Kittles have tailored their marketing rhetoric and the actual results of their tests to respond to the desires of their clientele, and their success at gaining the involvement of numerous Black celebrities and respected African American public figures, such as Henry Louis Gates, Jr., who have acted independently as vocal advocates of the tests. Moreover, the company's notable emphasis on encouraging customers to use their results to create interpersonal, charitable and business links with their newfound African "genetic cousins", 33 contributes to the idea that taking a DNA test with African Ancestry is not merely a self-contained or isolated activity, but rather part of a broader life experience.

It is perhaps precisely because of African Ancestry's success at encouraging its customers to invest financially, psychologically, and socially in its genetic identities, that the company has been the target of virulent criticisms from the academic sphere since its very inception. On a basic level, some of these criticisms have highlighted the existence of weaknesses in the scientific methodology used by African Ancestry (Rotimi 2003; Bolnick et al. 2007; Bandelt et al. 2008; Duster 2011) - a fact that has also been openly recognized by Kittles in the past. For instance, in a 2004 paper coauthored with Mark Shriver, he noted that the mtDNA and Y-Chr sequences analyzed for the company's MatriClan ${ }^{\mathrm{TM}}$ and PatriClan ${ }^{\mathrm{TM}}$ tests, respectively, make up only 
around one per cent of the entire human genome (Shriver and Kittles 2004, 612), and thus relate to only two specific lineages of a customer's family tree out of more than one thousand, going back just ten generations into the past. In an interview for the BBC documentary Motherland (2003), which followed three British Afro-Caribbean roots-seekers in their attempts to use mtDNA and Y-Chr analyses to retrace their ancestral African origins, Kittles acknowledged the limitations that this imposed upon the scope of such "ancestry" estimations, stating:

[It's] better than nothing, that's what I say! It's sort of like walking in a very dark room, and looking around for the light switch. And in this situation, maybe you find a flashlight, and that flashlight is enough light for you to maneuver in the room. And it's... I feel it's a tremendous feeling when you do connect and find a potential ancestor. (Baron 2003)

Nonetheless, Kittles' recognition of this fundamental constraint to African Ancestry's tests seems to be contradicted by the company's gesture of presenting certificates of ancestry to customers - an act that may be interpreted by customers as signaling that the test's results resume the entirety of their family origins, rather than a mere fraction of them.

In the same paper, Shriver and Kittles also acknowledged limitations regarding the reliability with which certain customer haplotypes can be matched to specific "ethnic" groups or geographic regions, stating:

The accuracy of lineage matching depends on the size and sampling of the database that is used to match mtDNA or Y-chromosome lineages to particular populations or geographical regions. The level of geographical resolution depends on both the sampled haplotype and the populations included in the database [...]. Many databases that are derived from published research are too small and lack samples in certain geographical regions. Nonetheless, the high regional specificity of mtDNA and Y-chromosome haplotypes means that some less common lineages can be traced to particular ethnic groups or locales. However, tracing the more common haplotypes to a particular location is problematic. (Shriver and Kittles 2004, 612-13)

In order to deal with this constraint, since the late 1990s Kittles has worked on building up an exclusive African Lineage Database, which, according to the African Ancestry website, is currently the world's largest for the region, including "over 30,000 maternal and paternal lineages from more than 30 countries and several hundred ethnic groups". ${ }^{34}$ The database constitutes one of African Ancestry's most important unique selling points, and is significant in helping the company stand out from other market competitors. As a result, the database has thus far remained private, and, consequently, so has important information regarding, for instance, the scope of its coverage of African regions and populations, the issue of whether all of the populations it comprises are made up of roughly similar number of sampled individuals, and the definition of what constitutes an "ethnic" group for the purposes of the database. As we saw above, all of these questions contribute significantly to geneticists' assessments of the robustness of their biogeographical estimations; in this 
commercial setting, however, such important details remain unavailable to scientific peers and customers alike.

This lack of transparency regarding the company's reference database was one of the main complaints raised against African Ancestry by Henry Louis Gates, Jr., shortly after the release of African American Lives in 2007, when he announced his plans to open his own rival genetic "ancestry" testing company (Winstein 2007). Gates had originally invited Kittles to provide the DNA analyses for African American Lives after the latter matched his mtDNA to the Nubian people of Sudan and Egypt in the early 2000s. However, for the filming of the show Gates' mtDNA was reanalyzed, and the results indicated on the contrary that the vast majority of haplotype matches were found in Western Europe, "between Paris and Dublin" (Judd 2006). Kittles subsequently conceded that the latter result was more likely to be correct, putting his own erroneous estimate down to the scarcity of European samples in the African Ancestry database at the company's outset (Winstein 2007). Gates, on the other hand, alleged that Kittles had been aware of the unlikelihood of him being descended from a Nubian individual, given the historical trade routes of the transatlantic trade, and stated that the company had simply provided him with the result they believed he wanted to hear (Nixon 2007).

By creating his own DTC testing company, AfricanDNA, Gates hoped to remedy some of the methodological drawbacks that afflicted African Ancestry; in particular, he aimed to reinforce the historical accuracy of the biogeographical estimates by including elements of the customer's personal genealogical data in the genetic analyses. To do so, Gates teamed up with historians Linda Heywood and John Thornton, both of whom had acted as academic consultants for the series African American Lives. In an interview conducted in April 2014, ${ }^{36}$ Thornton recalled that, during their stint working for the show, the production team had made it clear that they were keen to establish "tribal" labels for each of the guests, through the use of Kittles' DNA testing technologies. The role of the two historians, therefore, would be to receive the names of tribes identified by the genetics team, and create stories to explain how an individual from that tribe could plausibly have gotten from Africa to America during the period of the transatlantic trade. It was not until after the filming had concluded that Heywood and Thornton began to learn more about the methodological limitations inherent to the DNA testing process, and therefore to question the validity of the narratives that they had constructed to justify them.

In their subsequent roles as historical consultants for AfricanDNA, Thornton and Heywood decided to develop a more sophisticated methodology that would attempt to line up customers' genetic data with contextual genealogical information, thus providing more historically robust results. This time, rather than starting with the genetic match in Africa and trying to create a suitable historical narrative to fit, the principle was to begin by analyzing the historic trade routes to the most common US ports where captive Africans were disembarked, and then to work backwards from there to identify possible ports of origin in Africa. Using maps of the standard shipping patterns and trade routes between North America and different parts of Africa, they could discard "outliers" - genetic matches that fell too far from the ports 
habitually involved in the transatlantic trade - and instead home in on regions and groups where the customer's ancestor was more likely to have originated, without necessarily pinpointing one specific "tribe". 37 For Thornton, this solution was more satisfactory than the approach used by African Ancestry, since it provided "squishier" results - i.e. it allowed analysts to highlight a selection of possible countries and groups of origin, rather than arbitrarily picking one "ethnic" group and portraying it as a definite and unique match.

It is worth noting that, by Heywood and Thornton's standards, the genetic results provided to the participants of African American Lives and to AfricanDNA customers could only be considered reliable and "truthful" if they were able to be placed within the specific historical context of the transatlantic trade in enslaved Africans. Although any exact genetic match with another individual concretely indicates biological descent from a common ancestor - and therefore may logically be characterized by American genealogical conventions as signaling that the two people are biologically "related" - what mattered to Heywood and Thornton was to establish precisely which matches were the result of an ancestral link dating back to just two to four hundred years ago, rather than thousands of years in the past. This raises another issue with regards to the historic authenticity of genetic "ancestry" results: namely, whether the territorial distribution and demographic constitution of "ethnic" groups today can be considered to be reflective of the form and boundaries of African societies between two and four centuries ago. While Heywood and Thornton work from the premise that African populations have probably remained relatively stable over the past few centuries - a point that has nonetheless been hotly debated by some scholars (see for example: Berman 1998; MacEachern 2000; Rotimi 2003; Braun and Hammonds 2008) - they also concede that the question of the historical authenticity may not be as important to "ancestry" test-takers as it is to academic researchers. For instance, in an article published on the African American news, culture, and opinion website The Root in 2011, in which the pair attempted to summarize the different ways in which African "ethnic" labels have been used and conceptualized over the past three centuries, they concluded:

For people seeking their roots, it is probably not as important to link to a long-lost political group or try to locate the 18th-century name of genetic ancestors. The real contribution of the results provided by DNA is that they connect an African American living in, say, Boston or New Orleans with an African who identifies himself by a name say, Asante or Wolof - and who lives in Ghana or Senegal. The African American who shares genetic sequences with that person can link himself to that modern ethnic group. By matching genetic anomalies in an African American and an African, one can establish that these two individuals had common ancestors two centuries ago. (Heywood and Thornton 2011)

The predicament faced by Heywood and Thornton consists of the tension between wanting to provide African American clients with the specific "ethnic" affiliations they crave, and yet not wanting to present this information as absolute or deterministic with regards to customers' ancestral identities. To an extent, this 
dilemma seems to be inherent (although not exclusive) to commercial DTC "ancestry" testing ventures. While proposing to charge customers a fee for the service of analyzing their DNA may seem a logical and even necessary measure, given the significant material costs associated with genotyping techniques, the act of entering into a financial contract with members of the public also places an onus upon companies to fulfill the promises made in their marketing material, notably by providing a specific type of result. Companies therefore find themselves caught between conflicting interests: the financial impetus to create a product that will sell; the professional duty to provide a test whose results are considered scientifically (and perhaps historically) accurate; but also the moral, and in this case political, inclination to respond directly to the needs and desires of the client.

However, not all DTC "ancestry" testing initiatives aimed at the African American community have been set up within a commercial framework. In this respect, a pertinent counterexample to the cases of African Ancestry and AfricanDNA is that of the African-American DNA Roots Project, which was co-founded in 2000 by Bruce Jackson - then director of biotechnology at Massachusetts Bay Community College and Bert Ely, a geneticist at the University of South Carolina (Goldberg 2000). According to Jackson and Ely, who were interviewed separately in May $2014,{ }^{38}$ the Roots Project was always intended as both a non-profit venture and a scientific endeavor. The project's scientific aims were to collect genetics samples from North American, Caribbean, and African populations, and conduct analyses of regions of the mitochondrial genome, the Y-chromosome and the X-chromosome in order to understand how specific haplotypes had evolved in different populations since the transatlantic slave trade. The public dimension of the Roots Project was therefore developed in parallel to this research; as Jackson and Ely's database grew, they aimed to gradually gain a more sophisticated picture of the distribution of mtDNA and YChr variation among African regions and populations, and hopefully be able to make more accurate inferences about the origins of the African American lineages they were studying.

Although the lack of a commercial grounding meant that the project's scope was run on limited funding, it also meant that its coordinators felt unrestricted by the pressure to produce a specific result (e.g. "tribal" group names) for their participants. Indeed, despite the public-oriented nature of the project, Ely explained that he and Jackson continued to view it as a fundamentally scientific venture, and therefore to undertake their analyses according to the methodological strictures they observed in their ordinary research. In his words: "in science you go with an open mind, and let the data lead you". Initially, Jackson and Ely opted only to provide participants with the broadest and most confident inferences - for instance, whether their genetic haplotype was of African or European origin (Fitzgerald 2003). At the same time, they began to search for patterns in the distribution of specific haplotype sequences among different "ethnic" groups, in the hopes of ascertaining whether these markers could indeed be used to trace African Americans to a more specific origin. One experiment, begun in 2003, appeared to indicate the existence of a handful of "ethnic group specific mtDNA haplotypes", found among populations in Sierra Leone 
(Jackson et al. 2005) - a result that initially seemed an encouraging indication that the team would soon be able to provide precise ancestry inferences for the project's African American participants. The next step for Jackson and Ely was to test the effectiveness of their own proposed ancestry inference method, which they did by comparing a total of 171 African American mtDNA haplotypes to a database of 3,725 African mtDNA sequences, collected from various parts of the continent. The results, however, were disappointing: about half of all the African American sequences yielded multiple matches among the sampled African groups; only around five per cent were matched to a single "ethnic" group; and the remaining forty per cent finding no matches at all (Ely et al. 2006; 2007).

The ultimate test, Ely explained in his interview, was to see whether individuals of recent African origin, who knew their "ethnic" background, would be matched to the correct group. This experiment was performed on ten mtDNA sequences, donated by individuals of Senegalese, Nigerian, Cameroonian, Ghanaian, and Sierra Leonean origin. The results showed that five out of ten haplotypes were identical to sequences from at least two other countries as well as their country of origin - sometimes with matches as far-flung as Mozambique, Kenya, or Ethiopia. Three samples found no matches at all in the database. Two haplotypes found identical matches in countries that did not correspond to the sample donor's country of origin, therefore yielding "false positive" results (Ely 2006). For Ely, the experiments were conclusive. Rather than this being an issue of the science "not being quite there yet", as many had believed, he concluded that mtDNA sequences were simply not apt for inferring ancestry with the specificity that many African Americans were seeking.

Instead of looking for a "better" method or a different genetic marker that might be capable of conferring "ethnic" labels, Jackson - who continued running the project until 2014 - opted to modify the participants' expectations, providing them only with information that he saw as scientifically robust. A significant proportion of the project's participants, he stated in his interview, were African Ancestry customers who were unsure of their results' accuracy, and were looking for a second opinion. Jackson's response was invariably to reject the validity of the "ethnic" labels provided by the company - "You're not Mandinka... we don't know what you are!" - and instead to provide users with the name of their haplogroup (e.g. E1b2a), pointing out the geographic regions in which it was predominantly found. In Jackson's eyes, this constituted both a more scientific, and a more ethical way of presenting participants with their genetic information. Although it may not be as satisfying for test-takers to learn that they have not been matched to a specific "ethnic" group, he considered that it was nonetheless important for members of the public to realize that genetics "can't tell us everything about a person's identity".

As we can see from these discussions, many scientists and scholars involved in the design and analysis of personalized "ancestry" testing data base their approaches simultaneously upon their own criteria of scientificity and accuracy, as well as their ideas about what members of the public expect to gain from their DNA test, notably with regards to their own identity or those of their ancestors. Yet to what extent do these notions correspond to what test-takers actually hope to learn from their genetic 
"ancestry" data? Is it safe to assume, as Heywood and Thornton seem to suggest, that because products offering to link clients to a specific "ethnic" group or country produce respectable sales figures, these are the principal or sole details that interest them? And, with regards to Jackson and Ely's approach, how much importance do test-takers attribute to the value of historical authenticity and scientific robustness in their results, potentially at the expense of receiving simple and clear-cut answers?

While it is beyond the scope of this article to respond to these questions in full, one example from recent ethnographic research conducted by Abel on the social usages of genetic "ancestry" data by test-takers in the US can help to provide some pertinent details in this respect. ${ }^{39}$ Hasan's ${ }^{40}$ interest in African and African American history began while he was in elementary school, in the midst of the Civil Rights Movement. Although he does not remember having many conversations with his parents about his own family history while growing up, like many other African Americans of his generation he cites the release of Alex Haley's Roots as having sparked his lifelong "fascination" with genealogy. ${ }^{41}$ As a young adult, after an initial foray into the 1880 US Census, in which he managed to identify several of his direct ancestors, Hasan convinced himself that he could follow Haley's footsteps and trace some of his family lineages all the way back to Africa. Despite gradually realizing that this objective would be harder to achieve than he initially hoped, the idea of pinpointing the specific locations where his African ancestors had lived stayed with Hasan, becoming one of the motors of his genealogical research. Therefore, when he came across African Ancestry's testing products in the early 2000s, he jumped at the chance to find out his African ancestral origins.

Hasan took two tests with African Ancestry. In his words:

The experience lived up to the expectations, but with a twist. The mtDNA test that I took was able to trace my maternal side back to Sierra Leone and give a probable sense of the ethnic group from which that side originated. Mine was the Temne and Fulani tribes. The first read on my paternal test, the Y-DNA test, was inconclusive and that was disappointing. It was suggested that my deep ancestry paternal heritage might be Asian or Caucasian, even though all of my recent ancestry - father, grandfather, etc. - were of African descent. Not totally understanding the difference between deep and recent ancestry, I pushed back fairly hard on this assumption and asked them to 'check again when you get additional and diverse samples of DNA'. Nine months later they advised that there was a match with the Hausa ethnic group from Nigeria. I was elated. I also learned - a few years later - that this 'result' is most likely not accurate. Approximately $30 \%$ of all African Americans who are descended from those involved with the US slave trade have a European Y (paternal) deep ancestor; most often via the practice of raping African female slaves.

Following his initial experience with African Ancestry, Hasan went on to purchase additional mtDNA, Y-chromosome, and autosomal DNA tests through a number of other companies, in order to compare the results and services they offered. This additional testing experience led him to discover some of the technical limitations of particular types of test, and to appreciate the varying levels of accuracy between similar products supplied by different companies. Nowadays, he has learnt to "take 
every result with a grain of salt", and when buying new tests he typically favors firms with a good scientific reputation and a robust database (particularly with regards to African populations), who offer clients the possibility of downloading and owning their own genomic data. At the same time, though, Hasan does not necessarily dismiss the outcomes of tests he considers to be relatively unreliable. For instance, despite noting that his African Ancestry PatriClan match to the Nigerian Hausa group was contradicted by subsequent Y-Chr analyses from different companies, which indicated a European haplogroup, Hasan affirms that it is the former result that he will pass on to his children in order to give them a sense of "where they came from outside of slavery".

This brief illustration offers a number of points that are relevant to our discussion. Firstly, many first-time test-takers set out with high and often unrealistic expectations regarding the level of accuracy and precision involved in DNA "ancestry" analyses, usually based on promises laid out in companies' marketing material. In Hasan's case, it was only his instinctive rejection of the results for one of his analyses that led him to question the tests' overall validity, and the fact that he was able to compare the results provided by different companies that gradually led him to moderate his own expectations regarding the scope and robustness of his genetic "ancestry" inferences. This tendency to compare one's results with more than one company is by no means unusual among DNA test-takers (particularly among amateur genealogists, who are accustomed to the idea of checking the reliability of their sources), and seems to offer strong evidence of the interest shown by customers in verifying the quality of their results.

At the same time, Hasan's account also illustrates the pragmatic way in which testtakers tend to interpret, negotiate, adopt, and reject the "ethnic" and "ancestral" categories indicated in their genetic results, depending on the extent to which the outcomes reinforce or diverge from their desired identity. For instance, although Hasan was skeptical about the robustness of the eventual Y-Chr result offered by African Ancestry, the fact that it was offered to him by the company was taken as a mark of scientific legitimacy, which subsequently lent strength and authenticity to the narrative he would later pass on to his children, which, in turn, may eventually become solidified as part of their own genealogical heritage. This chain of events demonstrates, on the one hand, the highly subjective criteria used by many test-takers to determine the "truth" of certain pieces of genetic evidence, as they relate to their own chosen narrative of identity. On the other, it illustrates the symbolic weight that - by virtue of their scientific reputation and institutional standing - "ancestry" testing companies can offer to such narratives, regardless of the speculative nature of individual results.

Finally, it is worth mentioning the vast spectrum of uses to which test-takers put their DNA "ancestry" data. While a large proportion of customers, like Hasan, are initially attracted by the idea of discovering their ancestral origins or "ethnic" makeup, many also welcome the possibility of being able to take ownership of their own genetic data, and to use it for purposes that they may not initially have anticipated. Today, market leaders such as FamilyTreeDNA, 23andMe, and AncestryDNA 
routinely offer their customers the possibility of downloading their raw DNA data, and supply them with a range of online tools and utilities designed to enable them to pursue their own research goals, particularly with regards to their personal genealogical studies. An example of such features are "relative matching" utilities, which link customers automatically to fellow test-takers within the company's database, providing an estimated degree of relatedness according to the amount of DNA segments they share across the genome. Already, many Black genealogists have begun to take advantage of these tools to guide their family history research, and to reveal kinship ties that were lost generations before through enforced separations within the context of US slavery. Such activities offer productive new means of combining historical and genetic data, in ways that do not necessarily hinge upon the potentially chimeric motivation of uncovering a pristine pre-colonial "ethnic" identity, but rather upon piecing together family histories that can offer multi-faceted views of the social complexities of slavery.

\section{Conclusions}

We began this article by referring to the ongoing difficulties in fostering productive interdisciplinary discussions between geneticists and social scientists, over the extent to which genetic technologies can shed light on the identities and geographic origins of individuals displaced by the transatlantic trade in enslaved Africans. The roots of this impasse, we argued, can be traced back to theoretical shifts that marked the divergence of the two disciplines in the post-war era. For social scientists, the idea of using genetics to engage with the fundamentally social issues of African-descendant communities' searches for identity and origins is often interpreted as signaling a return to old essentialisms. Meanwhile, many geneticists have also raised concerns about the ways in which such technologies have been adapted and commercialized to provide personalized "ancestry" testing products to the general public; yet, at the same time, they defend the new opportunities that these analyses can present in terms of providing new forms of evidence in the context of studies of the histories and legacies of transatlantic slavery.

In an attempt to move beyond these entrenched positions, we chose to focus our discussion upon the reliability and precision of individual genetic "ancestry" estimations, interrogating the extent to which these processes can be said to live up to their reputation for uncovering hard "truths" about the origins of individuals displaced by the transatlantic trade, and their descendants. In the first section, we provided an in-depth description of how such procedures are carried out in the context of aDNA research studies, based on the experiences of Abel and other colleagues from the EUROTAST network. Here, we sought not only to highlight concrete ways in which technological advancements have improved the scope and resolution of such analyses over the past fifteen years - but also to underline and explain the inherent constraints to these methods, and how scientists deal with them in the interpretation of their results. In other words, we aimed to both justify and mitigate the field's reputation as an "exact" science - a step that we see as critical to 
constructing an informed debate about the opportunities and limitations that these methods can offer to the study of the origins of enslaved Africans. In this respect, it is important to acknowledge that neither genetic nor historical approaches alone can provide a definitive account of the identities and lived experiences of individuals displaced by the slave trade; however, through sustained interdisciplinary discussions and careful methodological planning, the combined analysis of historical, archaeological, anthropological, and molecular data can offer promise in terms of piecing together a more complete and multifaceted picture of the past.

In the second section, we complemented our initial discussion with an examination of how genetic "ancestry" testing technologies have been adapted and presented to African American roots-seekers, most famously by the company African Ancestry - an offshoot of the New York African Burial Ground project - but also by two other rival initiatives spearheading alternative commercial and not-for-profit models. Once again, our analysis was led by the themes of accuracy and reliability, to which we added the additional issue of scientific transparency. By exploring the testimonies of scholars and scientists linked to the company AfricanDNA and the African-American DNA Roots Project, we sought to illustrate the often conflicting moral, scientific, and commercial stakes that play into the ways in which "ancestry" test-providers choose to either mitigate or clarify the inherent issues of statistical robustness and historical accuracy present in their products. Such considerations are often predicated upon test creator's beliefs and/or ideological agendas regarding the potential of such products to help reinforce the individual identity claims of Black Americans, and to strengthen transatlantic links between African and African American communities. Yet, drawing upon the example of one "genetic genealogist", we argued that the predominant focus upon providing simple and unambiguous "ethnic" affiliations may risk misleading customers about the reliability of their results, while also failing to cater to the their potentially varied interests. Although the financial stakes involved in the genetic "ancestry" industry make it unlikely that companies will open up the black box of their reference datasets in the near future, it is nonetheless encouraging to see that many enterprises are moving towards a policy of greater transparency over their testing procedures, thereby allowing customers to progress beyond the search for a specific "ethnic" origin, by taking control of their genomic data in the pursuit of their personal research goals.

The final word in the Copenhagen debate referenced at the beginning of this article was had by the Danish filmmaker Alex Frank Larsen, who put forward his view that DNA studies could "help solve the crime called slavery". The pronouncement brought a somewhat uneasy truce upon the gathering, as the session drew to an end. Here, we feel it is worth returning to these words, offered by one of the few nonacademics present at the event, who, in the heat of our discussion, provided a calm reminder of the continuing symbolic power of genetics in the collective consciousness of the general public. As we have attempted to show in this paper, recent advances in the field of modern and ancient DNA studies have indeed allowed scientists to tap novel sources of biohistorical information, thus opening up new possibilities for shedding light upon the histories of individuals displaced by the 
transatlantic trade in enslaved Africans. The advent of DTC genetic "ancestry" testing has been welcomed enthusiastically by many members of the Africandescendant community in the US and elsewhere, while the successful use of aDNA analyses to estimate the origins of long-dead individuals has been hailed as a new opportunity to break the silence on the tomb of slavery. Geneticists and social scientists, in their capacity as interpreters and mediators of this genetic knowledge, hold the responsibility to moderate the expectations of the public by emphasizing the inherent constraints, as well as the exciting opportunities posed by DNA testing technologies to provide the descendants of the enslaved with new tools to help recover the personal and communal histories that have long lain buried.

\section{Acknowledgements}

The authors would like to express their sincere gratitude to Odile Hoffmann, Myriam Cottias, Véronique Boyer, Tom Gilbert, Hannes Schroeder, María Ávila-Arcos, Andrés Moreno-Estrada, Karla Sandoval-Mendoza, and to their anonymous reviewers, for their insightful comments and critiques throughout the preparation of this manuscript. They also wish to thank the members of the EUROTAST network, whose extensive debates and discussions provided the inspiration for this article.

\section{Disclosure statement}

No potential conflict of interest was reported by the authors.

\section{Funding}

This work was supported by the EUROTAST project, a Marie Curie Actions Initial Training Network, funded by the European Union under the Seventh Framework Programme [grant number EUROTAST FP7-PEOPLE-2010].

\section{Notes}

1 Which Way Now? Understanding Transatlantic Slavery in Scandinavia, Septemper 27 , University of Copenhagen.

2 Throughout this article, terms such as ancestry, ethnicity, and race appear in inverted commas to denote that, in addition to the local nuance and semantic complexity they have taken on in different sociocultural contexts, these concepts are currently acquiring diverse layers of meaning as they become associated with genomic practices. Although it is beyond the scope of this paper to explore the particularities of these new usages, the use of "scare quotes" throughout the text is intended to signal the potential ambiguities of these terms.

3 Throughout this article, excluding direct citations, the terms White and Black are referred to with a capital letter to mark that they refer to socio-political categories. Rather than being endowed with any concrete or inherent meaning, they have been constructed, reconfigured and contested in myriad ways in different social and historical contexts.

4 In the early 1990s, plans for the construction of a 34-storey office building in lower Manhattan were halted after the rediscovery of the remains of a site identified in eighteenth-century maps as a "Negroes Burying Ground". The revelation of the cemetery's existence - of which the US General Services Administration (GSA) had been 
aware, although it had assumed that the burials would largely be destroyed by prior building works - and of the lack of plans to conduct a proper investigation into the site, provoked outrage from the local African-descendant community, who lobbied local governors and Congress for the implementation of an in-depth scientific study, directed by African American researchers. The result was the New York African Burial Ground project, an interdisciplinary effort led by researchers from Howard University, Washington DC, which aimed to shed light on the origins, living conditions, and identities of the more than 400 historic individuals buried on the site (La Roche and Blakey 1997; Parker Pearson 1999, 178-79).

5 As a research field, aDNA can be loosely defined as the study of DNA obtained from organisms that died decades, thousands, or even hundreds of thousands of years ago and, in most cases, have not been preserved for the purpose of genetic or genomic studies (Pääbo et al. 2004).

6 EUROTAST was a Marie Skłodowska-Curie Actions Initial Training Network, implemented from 2011 to 2015, which aimed to study the history and legacies of the transatlantic trade in enslaved Africans through multi- and interdisciplinary methods. The network included molecular biologists, bioinformaticians, archaeologists, historians, physical and social anthropologists from around the world, and its thirteen research projects were based in ten universities across Europe. For more information, see: http://eurotast.eu/ [accessed April 29, 2016].

7 The definition of what constitutes a human "population" in genetic terms has been the subject of great debate and controversy over the course of the past century. In the field of population genetics, the concept refers to the theoretical existence of breeding communities, whose members have come to share distinct gene pools due to generations of endogamy and mutual isolation (Dobzhansky 1950). Although critics from in and outside of the field have suggested that the structure of human genetic variation is more adequately visualized in terms of overlapping clines, rather than discrete populations (Gannett 2003; Reardon 2005, 32-42; Lipphardt 2012), the concept continues to provide a framework for expressing and interpreting the overall genetic similarity between individuals from around the world, according to the net quantity of shared variants found in their respective genotypes.

8 While the majority of the human genetic information is found in the nuclear genome, a small fraction is also held in the mitochondrion, an organelle involved in energy production, which is found by the thousand in each of the body's eukaryotic cells. In contrast to nuclear DNA, which is inherited from both parents, mtDNA (also known as the mitochondrial genome) is maternally inherited, and is therefore known as a uniparental genetic marker.

9 These parts of the genome, which are passed down from mother to child, and father to son, respectively, do not recombine during sexual reproduction, meaning that their sequence generally remains unchanged over many generations. Variations in mtDNA and nonrecombinant sequences of the Y-Chr, known as haplotypes, act as a biological record of random mutations that have accumulated in these sections of the genome over tens and hundreds of generations. By comparing these uniparental markers with haplotype frequencies around the world, researchers are able to map the geographical distribution of mtDNA and Y-Chr haplogroups according to the frequencies at which they are found in different populations and regions. 
10 Unlike mtDNA and non-recombining Y-Chr DNA (see note 9), autosomal DNA, which is found in the nuclear genome and comprises 22 pairs of autosomes, contains a mixture of maternally and paternally inherited genomic material, which is shuffled and recombined each generation through sexual reproduction. The nuclear genome therefore contains tracts of DNA inherited from direct biological ancestors over a number of generations; these tracts are reduced in size each generation, as genetic material is lost through recombination (see for example Coop 2013).

11 Technically known as Polymerase Chain Reaction (PCR) amplification, this term refers to the enzymatic process of exponentially copying a single fragment of DNA to generate thousands to millions of copies of a particular DNA fragment of interest - a necessary step before DNA sequencing.

12 The HVR-I is a specific segment of the mitochondrial genome that consists of 386 base pairs (Bandelt, Macaulay, and Richards 2006, 7), and contains no genes (coding DNA), meaning that it accumulates genetic mutations faster than the coding region of the mitochondrial genome (i.e. because mutations on the coding region would be more likely to have deleterious effects on the body, therefore making it less likely that these genes would be transmitted to another generation).

13 For in-depth discussions of the approaches used by population geneticists in an effort to gain "representative" samples of humankind's "diversity", see: Keita and Stewart (n.d.); National Research Council (1997); Gannett (2001; 2003); Reardon (2005); TallBear (2007).

14 However, even the use of extensive modern genetic datasets representing relatively dense sampling among populations and regions of interest may still not provide an ideal resource when attempting to estimate the origins of historic individuals, given that the current genetic diversity and the geographic distribution of modern populations does not necessarily reflect that of human populations living over two centuries ago, during the lifetimes of the individuals under study.

15 Although the study's authors provided no overt definition of "macroethnic" groups, their examples included "Fulbe peoples", "Yoruba peoples", "Hausa peoples", and "Mandinka peoples", suggesting that their working definition related to a conjunction of broad linguistic, cultural, and geographic markers.

16 Genome sequencing technologies were first developed by Sanger et al. in 1977. In 1986, Applied Biosystems (ABI) introduced automatic DNA sequencing through the use of specially developed computer programs. In 1996, DNA sequencing became truly automated with the introduction of the first commercial DNA sequencer that replaced manual pouring and loading gels with automated reloading mechanisms. New highthroughput technologies, which emerged in 2005, noticeably reduced the per-base sequencing cost, while at the same time significantly increasing the number of bases sequenced. In 2006, Illumina's Solexa Genome Analyzer introduced the new method of sequencing by synthesis chemistry into the market. Since then, other companies have put forward new sequencing technologies, offering different sequencing outputs and characteristics (e.g. SOLiD, Heliscope, Nanopor). For a more detailed description of the development of these technologies, see Rodríguez-Ezpeleta and Aransay (2012); Myllykangas, Buenrostro and Ji (2012).

17 The past twenty-five years have seen the launch of numerous large-scale international sampling projects, such as the Human Genome Diversity Project (HGDP), the International HapMap Project, the 1000 Genomes Project, and the Genographic Project, 
which have aimed to collect substantial amounts of empirical data in order to support studies into the biogeographical distribution of human genomic variation. However, researchers have been slow to gain a broad sampling coverage of African populations, despite the fact that the continent is home to the greatest level of human genetic diversity on the planet. This trend is gradually beginning to be reversed, however, with the efforts of the African Genome Variation Project (AGVP), an international partnership based at the Sanger Institute in Cambridge, UK, which to date has compiled a publicly available dataset comprising dense genotype data from 1,481 individuals and whole-genome sequences from 320 individuals corresponding to eighteen ethno-linguistic groups in subSaharan Africa (Gurdasani et al. 2015).

18 SNPs - random genetic mutations affecting just one loci (or "letter") in a given DNA sequence (Vignal et al. 2002) - are the evolutionary result of migrations, population bottlenecks, natural selection, and admixture events occurring over tens of thousands of years. Since the early 2000s, they have been used by geneticists to estimate the evolutionary origins of particular segments of the genome, based on the identification of the communities and geographic regions in which they are most commonly found today.

19 These technologies, which began to appear on the market in 2005, consist of experimental platforms for conducting mass parallel sequencing of DNA fragments, while reducing the costs and the overall processing time in comparison to pre-existing technologies (see note 16).

20 Through years of experimentation, specialists in the field have learnt that aDNA preservation varies greatly between samples and within sample types. The level of DNA preservation depends on a number of factors including the age of the samples, humidity and $\mathrm{pH}$ of the soil, and burial temperature, among others. Methodological optimizations are always needed in order to maximize the retrieval of endogenous DNA from the samples (i.e. DNA that comes from the organism itself and not from environmental microorganisms). In general, tooth or petrous bone samples are the preferred materials for conducting aDNA analyses, since they have been shown to preserve higher proportions of endogenous DNA than other skeletal elements (Adler et al. 2011; Pinhasi et al. 2012; Damgaard et al. 2015).

21 After extraction, aDNA must be prepared for HTS in what is called a library-building process, in which artificial DNA fragments (adapters) needed for sequencing are attached to the end-fragments of the extracted aDNA (Meyer and Kircher 2010). The aDNA library is sequenced in one of the available commercial sequencing platforms (e.g Illumina) following a shotgun sequencing approach, where a representative fraction of the total composition of the aDNA sample is sequenced.

22 Two WGE methods were used on the Sint Maarten samples to enrich for the human portion of DNA. This was done in collaboration with researchers at the Stanford University (Carpenter et al. 2013; MYcroarray 2015).

23 In their paper, Bryc et al. explain that in their own PCA plots the strongest differentiating axis found among the populations sampled was "linguistic classification corresponding to Chadic and Nilo-Saharan vs. Niger-Kordofanian ancestry". The researchers explain this trend as a genetic remnant of the Bantu expansion, a vast migration of agro-pastoralist populations that occurred around 4,000 years ago, originating in Cameroon or Nigeria and expanding through sub-Saharan Africa (Bryc et al. 2010; Marks et al. 2014).

24 It is this individual approach, and the focus on historic rather than modern individuals that differentiates this study from population-level studies that have so far constituted the 
main genetic approach to shedding light upon the origins of African-descendant communities in the Americas (e.g. Parra et al. 2001; Salas et al. 2004; Salas et al. 2005; Hünemeier et al. 2007; Tishkoff et al. 2009; Bryc et al. 2010; Stefflova et al. 2011).

25 See for example: Wade (2015); “Archaeology's editors reveal the year's most compelling finds", Archaeology, December 7, 2015 (http://www.archaeology.org/issues/2001601/features/3965-top-10-archaeological-discoveries-of-2015); Mohan (2015); Speksnijder (2015); "ADN en restos de esclavos permite determinar sus países de origen", Perú21, March 10, 2015 (http://peru21.pe/mundo/adn-restos-esclavos-permitedeterminar-sus-paises-origen-2213987); "Técnica permite identificar origem de escravos enviados à América", G1, March 10, 2015 (http://g1.globo.com/ciencia-esaude/noticia/2015/03/tecnica-permite-identificar-origem-de-escravos-enviadosamerica.html); "Centuries-old DNA reveals origins of enslaved Africans", BBC World Service, March 11, 2015 (https://hannesschroeder.files.wordpress.com/2015/03/bbcworld-service-interview.m4a) [accessed April 29, 2016].

26 This was one of the key aims of the EUROTAST project, which was designed to bring together different disciplinary approaches in order to create broader perspectives on how slavery shaped the cultural and biological experiences of people of African descent around the world.

27 To provide this information, we interviewed seven colleagues linked to the EUROTAST network who have previously been involved in genetic sampling projects and/or the compilation of reference datasets.

28 This is typically done by collaborating with anthropologists who already have strong links to the communities of interest, or by establishing contact with local volunteers who can act as mediators between the community, the researchers, and the study. Sampling generally takes place on an individual voluntary basis, although local leaders can often be influential in either encouraging or discouraging the participation of community members.

29 Many studies, such as the one conducted by Schroeder et al. (2015), do not carry out their own sampling projects, but rather rely upon published datasets that were collected and compiled by other research teams. In these cases, the researchers' interaction with the reference data panel begins at this point, by imposing specific thresholds to the quality control procedures, in accordance with their own research aims.

30 Until 1850, only heads of households were included in U.S. records. The 1850 and 1860 census records included the names of "free persons of color", but enslaved Blacks were listed only by number per household, and not name. The 1870 census was the first in which all American Blacks were listed by name, thus making it extremely difficult for most African American genealogists to trace their ancestors prior to this date (see Blockson and Fry 1991).

31 STRs are short sequences of DNA (usually between two and five base pairs in length), known as alleles or "markers", which are repeated end-to-end at different loci on the nonrecombining segment of the Y-chromosome. STRs on the Y-Chr are attributed a DNA YChromosome Segment (DYS) number, corresponding to their location on the chromosome, and a value, corresponding to the number of base pair repeats found there. While more than 100 STR markers have been discovered to date on the NRY, African Ancestry's PatriClanTM test examines just nine markers in order to match customers to Y-chromosome lineages in the company database. 
32 For example, in a message on the African Ancestry "Testimonials" webpage, "African Ancestry Family Member" Sheena Bouquet states: "In 2006, I made my first trip to the Motherland. When I returned to America, I decided that I needed to know where I came from. This was truly one of the greatest and proudest moments of my life. I made copies of the certificates and laminated them to show my family and friends - I walk with my copies everyday. Thank you for affording myself and others the opportunity to get to know our 'Roots'",

33 The "Community" page on the African Ancestry website informs customers that, by joining the company's online forum, they can share their results with others of the same ancestry; organize a family reunion to celebrate their ancestry; and support social causes and invest in Africa, among other things. In the past, Kittles has also publicly emphasized his hope that the use of his company's testing products would help Americans to forge stronger bonds with African communities. For instance, in an interview with a local Chicago newspaper published in 2009, Kittles stated: "I wanted [test-takers] to see themselves in Africa and recognize that these are people who are related to us and know that their issues are our issues and I wanted African-Americans to be comfortable lobbying and want to know more about the history and the politics and the current situation in Africa. I wanted to see people, let's say, like Isaiah Washington, who goes back to Sierra Leone and builds a school and a hospital and has lobbied there and here for the culture. It's exciting and important" (Oduah 2009).

34 See http://www.africanancestry.com/assets/pdf/LineageMap.pdf [accessed April 29, 2016].

35 AfricanDNA was set up in 2008 in partnership with Family Tree DNA, a genetic testing company established in 2000 by the entrepreneur Bennett Greenspan. The AfricanDNA website is run by Family Tree DNA, and its genetic analyses are performed at a commercial laboratory at the University of Arizona, run by the geneticist Michael Hammer (El-Haj 2012, 284).

36 Interview conducted by Abel on April 28, 2014 at the African American Studies Faculty, Boston University, MA.

37 The technique of using embarkation ports to estimate the geographic origins of captive Africans nonetheless incurs a degree of uncertainty, given historian Philip D. Morgan's observation that "ships designated as having boarded their slaves at a particular port did not always obtain all their slaves even from the coastal region of that port. The African point of embarkation may have simply been the last port of call” (P. D. Morgan 1997, 131).

38 Phone interviews conducted by Abel with Bruce Jackson on May 7, 2014, and with Bert Ely on May 9, 2014.

39 This interview was carried out by email correspondence between April 17 and 18, 2013, and is part of a larger research study into the social uses of DNA "ancestry" data by testtakers in the US and Brazil, carried out between September 2012 and August 2015.

40 At the request of the informant, we have used a pseudonym.

41 It is hard to overemphasize the extent to which Haley's Roots has influenced the African American imaginary by introducing a powerful narrative of origins, which for the first time popularized the belief that all descendants of the enslaved have the possibility of recovering their family history, which in turn can serve as an umbilical cord linking each individual back to an original African homeland and culture. The novel and accompanying television miniseries were released at the height of the "ethnic" turn in 
American culture - a period in which the descendants of recent European immigrants were attempting to dissociate themselves from the all-embracing label of Whiteness, which had become ever more tightly linked to the violent and oppressive racial politics of Jim Crow segregation - just as Black Americans were striving to forge new cultural and political links with emerging post-colonial African states (Omi and Winant 1994; Frye Jacobson 2006). The desire to claim authentic "ethnic" identities - principally through genealogical research and roots tourism, as well as targeted consumer practices (Comaroff and Comaroff 2009) - appears to have only strengthened over the intervening decades within US society, and can do much to explain the particular popularity of genetic "ancestry" and "ethnicity" testing technologies in the country, in comparison to other American societies with similar histories of immigration and slavery. For instance, recent ethnographic studies in countries such as Brazil and Colombia have indicated that, despite the recent progress made by national and local Black movements in terms of encouraging members of the public to take pride in their Black cultural heritage, public and private discussions of the outcomes of genetic "ancestry" studies tend to revolve around the notion of "racial" mixture (mestiçagem/mestizaje), which has long been central to national paradigms of identity in the region (see for example Neto, Santos, and Kent 2012; Kent, Santos, and Wade 2014; P. Wade et al. 2014; Kent et al. 2015).

\section{References}

Adler, C. J., W. Haak, D. Donlon, A. Cooper, and The Genographic Consortium. 2011. 'Survival and Recovery of DNA from Ancient Teeth and Bones'. Journal of Archaeological Science 38 (5): 956-64.

Allan, T. M. 1963. 'Hirszfeld and the ABO Blood Groups'. British Journal of Preventive \& Social Medicine 17: 166-71.

Bandelt, H.-J., V. Macaulay, and M. Richards, eds. 2006. Human Mitochondrial DNA and the Evolution of Homo Sapiens. Berlin: Springer.

Bandelt, H.-J., Y.-G. Yao, M. B. Richards, and A. Salas. 2008. 'The Brave New Era of Human Genetic Testing'. BioEssays 30 (11-12): 1246-51.

Barbujani, Guido, Arianna Magagni, Eric Minch, and L. Luca Cavalli-Sforza. 1997. 'An Apportionment of Human DNA Diversity'. Proceedings of the National Academy of Sciences 94 (9): 4516-19.

Baron, Archie. 2003. 'Motherland: A Genetic Journey'. BBC.

Berman, Bruce J. 1998. 'Ethnicity, Patronage and the African State: The Politics of Uncivil Nationalism'. African Affairs 97: 305-41.

Blakey, Michael L. 2001. 'Bioarchaeology of the African Diaspora in the Americas: Its Origin and Scope'. Annual Review of Anthropology 30: 287-422.

Blakey, Michael L. 2009. 'Introduction'. In Skeletal Biology of the New York African Burial Ground, edited by Michael L. Blakey and Lesley M. Rankin-Hill, 3-18. Washington DC: Howard University Press.

Blockson, Charles L., and Ron Fry. 1991. Black Genealogy. Baltimore: Black Classic Press. 
Bolnick, Deborah A., Duana Fullwiley, Troy Duster, Richard S. Cooper, Joan H. Fujimura, Jonathan Kahn, Jay S. Kaufman, et al. 2007. 'The Science and Business of Genetic Ancestry Testing'. Science 318 (October): 399-400.

Bouvier, Pierre. 1997. 'L'objet de La Socio-Anthropologie: Crise, Déstructuration, Recomposition, Perdurance'. Socio-Anthropologie 1. https://socioanthropologie.revues.org/27.

Braun, Lundy, and Evelynn Hammonds. 2008. 'Race, Populations, and Genomics: Africa as Laboratory'. Social Science \& Medicine 67: 1580-88.

Bryc, Katarzyna, Adam Auton, Matthew R. Nelson, Jorge R. Oksenberg, Stephen L. Hauser, Scott Williams, Alain Froment, et al. 2010. 'Genome-Wide Patterns of Population Structure and Admixture in West Africans and African Americans'. PNAS 107 (2): 786-91.

Callaway, Ewen. 2012. 'Ancestry Testing Goes for Pinpoint Accuracy'. Nature 486: 17.

Cann, Rebecca L., Mark Stoneking, and Allan C. Wilson. 1987. 'Mitochondrial DNA and Human Evolution'. Nature 325 (January): 31-36.

Carpenter, Meredith L, Jason D Buenrostro, Cristina Valdiosera, Hannes Schroeder, Morten E Allentoft, Martin Sikora, Morten Rasmussen, et al. 2013. 'Pulling out the 1\%: Whole-Genome Capture for the Targeted Enrichment of Ancient DNA Sequencing Libraries'. American Journal of Human Genetics 93 (5): 852-64. doi:10.1016/j.ajhg.2013.10.002.

Cavalli-Sforza, L. Luca. 1997. 'Genes, Peoples, and Languages'. PNAS 94 (July): 7719-24.

Cavalli-Sforza, L. Luca. 2005. 'The Human Genome Diversity Project: Past, Present and Future'. Nature Reviews 6: 333-40.

Comaroff, John L., and Jean Comaroff. 2009. Ethnicity, Inc. Chicago \& London: University of Chicago Press.

Coop, Graham. 2013. 'How Much of Your Genome Do You Inherit from a Particular Ancestor?' Genetics blog. The Coop Lab: Population and Evolutionary Genetics UC Davis. November 4. http://gcbias.org/2013/11/04/how-much-of-your-genomedo-you-inherit-from-a-particular-ancestor/.

Dade, Corey, Sarah A. Tishkoff, Linda Heywood, and Michael L. Blakey. 2013. 'Setting the Stage for Understanding Ancestry of African Americans'. presented at the The African Diaspora: Integrating Culture, Genomics and History, National Museum of Natural History, Smithsonian Institution, September 12. https://www.youtube.com/watch?v=9K4A7e3clMM.

Damgaard, Peter B., Ashot Margaryan, Hannes Schroeder, Ludovic Orlando, Eske Willerslev, and Morten E. Allentoft. 2015. 'Improving Access to Endogenous DNA in Ancient Bones and Teeth'. Scientific Reports 5 (June): 11184. doi:10.1038/srep11184.

Dobzhansky, Theodosius. 1950. 'Mendelian Populations and Their Evolution'. The American Naturalist 84: 401-18. 
Duster, Troy. 2011. 'Ancestry Testing and DNA: Uses, Limits, and Caveat Emptor'. In Race and the Genetic Revolution: Science, Myth, and Culture, edited by Sheldon Krimsky and Kathleen Sloan, 99-116. New York: Columbia University Press.

Elhaik, Eran, Tatiana Tatarinova, Dmitri Chebotarev, Ignazio S. Piras, Carla Maria Calò, Antonella De Montis, Manuela Atzori, et al. 2014. 'Geographic Population Structure Analysis of Worldwide Human Populations Infers Their Biogeographical Origins'. Nature Communications 5. doi:10.1038/ncomms4513.

El-Haj, Nadia Abu. 2012. The Genealogical Science: The Search for Jewish Origins and the Politics of Epistemology. Chicago \& London: University of Chicago Press.

Ely, B. 2006. 'Can a Database of mtDNA HvsI Sequences Properly Assign Africans to Their Country of Origin?' http://ww2.biol.sc.edu/ elygen/African\%20assignments.doc.

Ely, B., J. L. Wilson, F. L. C. Jackson, and B. A. Jackson. 2006. 'African-American Mitochondrial DNA Often Match mtDNAs Found in Multiple African Ethnic Groups'. BMC Biology 4 (34): 1-14.

Ely, B., J. L. Wilson, F. L. C. Jackson, and B. A. Jackson. 2007. 'Correction: African American Mitochondrial DNAs Often Match mtDNAs Found in Multiple African Ethnic Groups'. BMC Biology 5 (13): 1-5.

Fitzgerald, Brian. 2003. 'DNA Project Helps African-Americans Search for Ancestry'. B.U. Bridge, October 10. https://www.bu.edu/bridge/archive/2003/10-10/dna.html.

Foucault, Michel. 2003. 'Society Must Be Defended': Lectures at the Collège de France, 1975-76. Edited by Mauro Bertani, Alessandro Fontana, and François Ewald. Translated by David Macey. New York: Picador.

Frye Jacobson, Matthew. 2006. Roots Too: White Ethnic Revival in Post-Civil Rights America. Cambridge, MA and London, UK: Harvard University Press.

Fulwood III, Sam. 2000. 'His DNA Promise Doesn't Deliver'. Los Angeles Times, May 29. http://articles.latimes.com/2000/may/29/news/mn-35219.

Gannett, Lisa. 2001. 'Racism and Human Genome Diversity Research: The Ethical Limits of "Population Thinking", Philosophy of Science 68 (3): S479-92.

Gannett, Lisa. 2003. 'Making Populations: Bounding Genes in Space and in Time'. Philosophy of Science 70 (5): 989-1001.

Gates Jr., Henry Louis. 2009. In Search of Our Roots: How 19 Extraordinary African Americans Reclaimed Their Past. New York: Crown.

Goldberg, Carey. 2000. 'DNA Offers Link to Black History'. The New York Times, August 28. http://www.nytimes.com/2000/08/28/us/dna-offers-link-to-black-history.html.

Gonçalves, Vanessa F., Claudia M. B. Carvalho, Maria Cátira Bortolini, Sérgio P. Bydlowski, and Sérgio D. J. Pena. 2008. 'The Phylogeography of African Brazilians'. Human Heredity 65: 23-32.

Gurdasani, Deepti, Tommy Carstensen, Fasil Tekola-Ayele, Luca Pagani, Ioanna Tachmazidou, Konstantinos Hatzikotoulas, Savita Karthikeyan, et al. 2015. 'The African Genome Variation Project Shapes Medical Genetics in Africa'. Nature 517 (7534): 327-32. 
Haley, Alex. 1976. Roots. Garden City: Doubleday.

Hammer, M. F., A. B. Spurdle, T. Karafet, M. R. Bonner, E. T. Wood, A. Novelletto, P. Malaspina, et al. 1997. 'The Geographic Distribution of Human Y Chromosome Variation'. Genetics 145: 787-805.

Heywood, Linda, and John Thornton. 2011. 'Pinpointing DNA Ancestry in Africa'. The Root, October

http://www.theroot.com/articles/culture/2011/10/tracing_dna_not_just_to_africa_bu t_to_1_tribe.html.

Hünemeier, Tábita, Claudia M. B. Carvalho, Andrea Rita Marrero, Francisco M. Salzano, Sérgio D. J. Pena, and Maria Cátira Bortolini. 2007. 'Niger-Congo Speaking Populations and the Formation of the Brazilian Gene Pool: mtDNA and YChromosome Data'. American Journal of Physical Anthropology 133 (2): 854-67.

International Human Genome Sequencing Consortium. 2001. 'Initial Sequencing and Analysis of the Human Genome'. Nature 409 (6822): 860-921. doi: $10.1038 / 35057062$.

Jackson, B. A., J. L. Wilson, S. Kirbah, S. S. Sidney, J. Rosenberger, L. Bassie, J. A. D. Alie, D. C. McLean, W. T. Garvey, and B. Ely. 2005. 'Mitochondrial DNA Genetic Diversity among Four Ethnic Groups in Sierra Leone'. American Journal of Physical Anthropology 128 (1): 156-63.

Jackson, F. L. C., and L. F. J. Borgelin. 2010. 'How Genetics Can Provide Detail to the Transatlantic African Diaspora'. In The African Diaspora and the Disciplines, 75100. Bloomington, IN: Indiana University Press.

Jackson, F. L. C., A. Mayes, M. E. Mack, A. Froment, S. O. Y. Keita, R. A. Kittles, M. George, K. J. Shujaa, M. L. Blakey, and L. M. Rankin-Hill. 2009. 'Origins of the New York African Burial Ground Population: Biological Evidence of Geographical and Macroethnic Affiliations Using Craniometrics, Dental Morphology, and Preliminary Genetic Analyses'. In Skeletal Biology of the New York African Burial Ground Part I, edited by Michael L. Blakey and Lesley M. Rankin-Hill, 69-94. Washington DC: Howard University Press.

Jackson, F. L. C., and S. McDonald. 2008. 'The Biopolitics of Human Genetics Research and Its Application'. In Tactical Biopolitics: Art, Activism and Technoscience, edited by Beatriz da Costa and Kavita Philip, 193-204. Cambridge and London: MIT.

JBHE. 2000. 'Howard University Molecular Biologist Fails to Deliver on His African Ancestry Tracking System'. Journal of Blacks in Higher Education 29: 25-28.

Jobling, Mark A., and Chris Tyler-Smith. 2003. 'The Human Y Chromosome: An Evolutionary Marker Comes of Age'. Nature 4 (August): 598-612.

Jorde, L. B., W. S. Watkins, M. J. Bamshad, M. E. Dixon, C. E. Ricker, M. T. Seielstad, and M. A. Batzer. 2000. 'The Distribution of Human Genetic Diversity: A Comparison of Mitochondrial, Autosomal, and Y-Chromosome Data'. American Journal of Human Genetics 66: 979-88.

Judd, Graham. 2006. 'Beyond the Middle Passage'. African American Lives. PBS. 
Kaestle, Frederika A. 2003. 'The Good, the Bad, and the Ugly: Promise and Problems of Ancient DNA for Anthropology'. In Genetic Nature/Culture, 278-96. Berkeley, Los Angeles, London: University of California Press.

Keita, Shomarka, and James Stewart. 2016. 'Ethics, Identity, Genetics, Patrimony and Power in the Harvesting of DNA from Africa'. GeneWatch. Accessed April 29. http://www.councilforresponsiblegenetics.org/genewatch/GeneWatchPage.aspx?pa geId $=273$.

Keller, Andreas, Angela Graefen, Markus Ball, Mark Matzas, Valesca Boisguerin, Frank Maixner, Petra Leidinger, et al. 2012. 'New Insights into the Tyrolean Iceman's Origin and Phenotype as Inferred by Whole-Genome Sequencing'. Nat Commun 3 (February): 698. doi:10.1038/ncomms1701.

Kent, Michael, Vivette García-Deister, Carlos López-Beltrán, Ricardo Ventura Santos, Ernesto Schwartz-Marín, and Peter Wade. 2015. 'Building the Genomic Nation: "Homo Brasilis" and the "Genoma Mexicano" in Comparative Cultural Perspective'. Social Studies of Science, November. doi:10.1177/0306312715611262.

Kent, Michael, Ricardo Ventura Santos, and Peter Wade. 2014. 'Negotiating Imagined Genetic Communities: Unity and Diversity in Brazilian Science and Society'. American Anthropologist 116 (4): 1-13.

La Roche, Cheryl J., and Michael L. Blakey. 1997. 'Seizing Intellectual Power: The Dialogue at the New York African Burial Ground'. Historical Archaeology 31 (3): 84-106.

Lawler, Andrew. 2016. 'Tracing Slaves to Their African Homelands'. National Geographic, February 4. http://news.nationalgeographic.com/2016/02/160204-tracing-slave-dnaafrica-mesoamerica/.

Lewontin, Richard. 1972. 'The Apportionment of Human Diversity'. Evolutionary Biology 6: 381-98.

Lipphardt, Veronika. 2012. 'Isolates and Crosses in Human Population Genetics: Or, A Contextualization of German Race Science'. Current Anthropology 53 (Supplement 5): S69-82.

MacEachern, Scott. 2000. 'Genes, Tribes, and African History'. Current Anthropology 41 (3): 357-84.

Mack, Mark E., and Michael L. Blakey. 2004. 'The New York African Burial Ground Project: Past Biases, Current Dilemmas, and Future Research Opportunities'. Society for Historical Archaeology 38 (1): 10-17.

Marks, Sarah J., Francesco Montinaro, Hila Levy, Francesca Brisighelli, Gianmarco Ferri, Stefania Bertoncini, Chiara Batini, et al. 2014. 'Static and Moving Frontiers: The Genetic Landscape of Southern African Bantu-Speaking Populations'. Molecular Biology and Evolution 32 (1): 29-43.

Meyer, Matthias, and Martin Kircher. 2010. 'Illumina Sequencing Library Preparation for Highly Multiplexed Target Capture and Sequencing'. Cold Spring Harbor Protocols 2010 (6): pdb.prot5448. doi:10.1101/pdb.prot5448. 
Mohan, Geoffrey. 2015. 'DNA from Ancient Teeth Solves Mystery of African Slave Burial'. LA Times, March 10. http://www.latimes.com/science/sciencenow/la-sci-sn-dnamystery-african-slave-burial-20150309-story.html.

Montagu, M. F. Ashley. 1945. Man's Most Dangerous Myth: The Fallacy of Race. Kindle Edition. New York: Columbia University Press.

Morgan, Philip D. 1997. 'The Cultural Implications of the Atlantic Slave Trade: African Regional Origins, American Destinations and New World Developments'. Slavery \& Abolition: A Journal of Slave and Post-Slave Studies 18 (1): 122-45.

Morgan, T. H. 1910. 'Sex Limited Inheritance in Drosophilia'. Science 32 (812): 120-22.

MYcroarray. 2015. MYbaits In-Solution Sequence Capture for Targeted High-Throughput Sequencing: User Manual. Version 3.01. Ann Arbor: Biodiscovery.

Myllykangas, Samuel, Jason Buenrostro, and Hanlee P. Ji. 2012. 'Overview of Sequencing Technology Platforms'. In Bioinformatics for High Throughput Sequencing, edited by Naiara Rodríguez-Ezpeleta, Michael Hackenberg, and Ana M. Aransay, 11-25. New York \& London: Springer.

National Research Council. 1997. Evaluating Human Genetic Diversity. Washington DC: National Academy Press.

Nelson, Alondra. 2016. The Social Life of DNA: Race, Reparations, and Reconciliation after the Genome. Boston, MA: Beacon Press.

Nelson, Alondra, and Jeong Won Hwang. 2012. 'Roots and Revelation: Genetic Ancestry Testing and the YouTube Generation'. In Race After the Internet, edited by Lisa Nakamura and Peter A. Chow-White, 271-90. New York \& Abingdon: Routledge.

Neto, Verlan Valle Gaspar, Ricardo Ventura Santos, and Michael Kent. 2012. 'Biorrevelações: Testes de Ancestralidade Genética Em Perspectiva Antropológica Comparada'. In Identidades Emergentes, Genética E Saúde: Perspectivas Antropológicas, edited by Ricardo Ventura Santos, Sahra Gibbon, and Jane Beltrão, 233-63. Rio de Janeiro: Fiocruz, Garamond.

Nixon, Ron. 2007. 'DNA Tests Find Branches but Few Roots'. The New York Times, November 25. http://www.nytimes.com/2007/11/25/business/25dna.html?pagewanted=all\&_r=0.

Novembre, John, Toby Johnson, Katarzyna Bryc, Zoltán Kutalik, Adam R. Boyko, Adam Auton, Amit Indap, et al. 2008. 'Genes Mirror Geography within Europe'. Nature 456: $98-103$.

Oduah, Chika S. 2009. 'The DNA Debate: Can It Help Black Chicagoans Find African Relatives?' Medill Reports Chicago, December 1. http://newsarchive.medill.northwestern.edu/chicago/news.aspx?id=150565.

Omi, Michael, and Howard Winant. 1994. Racial Formation in the United States: From the 1960s to the 1990s. Second Edition. New York \& London: Routledge.

Pääbo, S., H. Poinar, D. Serre, V. Jaenicke-Despres, J. Hebler, N. Rohland, M. Kuch, L. Vigilant, and M. Hofreiter. 2004. 'Genetic Analyses from Ancient DNA'. Annual Review of Genetics 38: 645-79. 
Parker Pearson, Mike. 1999. The Archaeology of Death and Burial. College Station: Texas A\&M University Press.

Parra, E. J., R. A. Kittles, G. Argyropoulos, C. Pfaff, K. Hiester, C. Bonilla, N. Sylvester, et al. 2001. 'Ancestral Proportions and Admixture Dynamics in Geographically Defined African Americans Living in South Carolina'. American Journal of Physical Anthropology 114: 18-29.

Pinhasi, Ron, Mark G. Thomas, Michael Hofreiter, Mathias Currat, and Joachim Burger. 2012. 'The Genetic History of Europeans'. Trends in Genetics 28 (10): 497-505.

Rasmussen, Morten, Xiaosen Guo, Yong Wang, Kirk E. Lohmueller, Simon Rasmussen, Anders Albrechtsen, Line Skotte, et al. 2011. 'An Aboriginal Australian Genome Reveals Separate Human Dispersals into Asia'. Science 334 (6052): 94-98. doi:10.1126/science.1211177.

Rasmussen, Morten, Yingrui Li, Stinus Lindgreen, Jakob Skou Pedersen, Anders Albrechtsen, Ida Moltke, Mait Metspalu, et al. 2010. 'Ancient Human Genome Sequence of an Extinct Palaeo-Eskimo'. Nature 463: 757-62. doi:10.1038/nature08835.

Reardon, Jenny. 2005. Race to the Finish: Identity and Governance in an Age of Genomics. Princeton, NJ: Princeton University Press.

Roberts, Dorothy. 2011. Fatal Invention: How Science, Politics, and Big Business Re-Create Race in the Twenty-First Century. New York \& London: The New Press.

Rodríguez-Ezpeleta, Naiara, and Ana M. Aransay. 2012. 'Introduction'. In Bioinformatics for High Throughput Sequencing, edited by Naiara Rodríguez-Ezpeleta, Michael Hackenberg, and Ana M. Aransay, 1-9. New York \& London: Springer.

Rosenberg, Noah A., Jonathan K. Pritchard, James L. Weber, Howard M. Cann, Kenneth K. Kidd, Lev A. Zhivotovsky, and Marcus W. Feldman. 2002. 'Genetic Structure of Human Populations'. Science 298: 2381-85.

Rosser, Zoë H, Tatiana Zerjal, Matthew E Hurles, Maarja Adojaan, Dragan Alavantic, António Amorim, William Amos, et al. 2000. 'Y-Chromosomal Diversity in Europe Is Clinal and Influenced Primarily by Geography, Rather than by Language'. American Journal of Human Genetics 67 (6): 1526-43.

Rotimi, Charles N. 2003. 'Genetic Ancestry Tracing and the African Identity: A DoubleEdged Sword?’ The American Journal of Human Genetics 86: 661-73.

Salas, Antonio, Ángel Carracedo, Martin Richards, and Vincent Macaulay. 2005. 'Charting the Ancestry of African Americans'. American Journal of Human Genetics 77: 676-80.

Salas, Antonio, Martin Richards, María-Victoria Lareu, Rosaria Scozzari, Alfredo Coppa, Antonio Torroni, Vincent Macaulay, and Ángel Carracedo. 2004. 'The African Diaspora: Mitochondrial DNA and the Atlantic Slave Trade'. American Journal of Human Genetics 74 (3): 454-65.

Sandoval-Velasco, Marcela, María C. Moreno-Mayor, María C. Ávila-Arcos, Kate RobsonBrown, M. Thomas P. Gilbert, and Hannes Schroeder. 2015. 'The Freed Slaves of Saint Helena: Genomic Analyses of 19th Century Human Remains Shed Light on Enslaved Africans' Geographic Origins and Population Diversity'. In Society for 
American Archaeology and European Association for Archaeologists. Willemstad, Curação.

Schroeder, Hannes, María C. Ávila-Arcos, Anna-Sapfo Malaspinas, G. David Poznik, Marcela Sandoval-Velasco, Meredith L. Carpenter, José Víctor Moreno-Mayar, et al. 2015. 'Genome-Wide Ancestry of 17th-Century Enslaved Africans from the Caribbean'. PNAS. doi:10.1073/pnas.1421784112.

Schroeder, Hannes, Jay B. Haviser, and T. Douglas Price. 2012. 'The Zoutsteeg Three: Three New Cases of African Types of Dental Modification from Saint Martin, Dutch Caribbean'. International Journal of Osteoarchaeology. doi:10.1002/oa.2253.

Serre, David, and Svante Pääbo. 2004. 'Evidence for Gradients of Human Genetic Diversity Within and Among Continents'. Genome Research 14: 1679-85.

Shriver, Mark D., and Rick A. Kittles. 2004. 'Genetic Ancestry and the Search for Personalized Genetic Histories'. Nature Reviews 5: 611-18.

Shriver, Mark D., Michael W. Smith, Li Jin, Amy Marcini, Joshua M. Akey, Ranjan Deka, and Robert E. Ferrell. 1997. 'Ethnic-Affiliation Estimation by Use of PopulationSpecific DNA Markers'. American Journal of Human Genetics 60: 957-64.

Skoglund, Pontus, Helena Malmström, Maanasa Raghavan, Jan Storå, Per Hall, Eske Willerslev, M. Thomas P. Gilbert, Anders Götherström, and Mattias Jakobsson. 2012. 'Origins and Genetic Legacy of Neolithic Farmers and Hunter-Gatherers in Europe'. Science 336 (6080): 466-69. doi:10.1126/science.1216304.

Southall, Aidan W. 2010. 'The Illusion of Tribe'. In Perspectives on Africa: A Reader in Culture, History, and Representation, edited by Roy Richard Grinker, Stephen C. Lubkemann, and Christopher B. Steiner, 2nd ed, 83-94. Chichester: WileyBlackwell.

Souza, Sheila Mendonça de, Della Collins Cook, Murilo Quintana Bastos, and Ricardo Ventura Santos. 2012. 'Cemitério Dos Pretos Novos: Técnicas Modernas Ajudam a Compreender Questões Da Escravidão’. Ciência Hoje 49 (291): 22-27.

Speksnijder, Cor. 2015. 'Herkomst Slaven Achterhaald via Dna'. De Volkskrant, March 10. http://www.volkskrant.nl/wetenschap/herkomst-slaven-achterhaald-viadna a3893076.

Stefflova, Klara, Matthew C. Dulik, Jill S. Barnholtz-Sloan, Athma A. Pai, Amy H. Walker, and Timothy R. Rebbeck. 2011. 'Dissecting the Within-Africa Ancestry of Populations of African Descent in the Americas'. PLoS One 6 (1). doi:10.1371/journal.pone.0014495.

Stoneking, M., and H. Soodyall. 1996. 'Human Evolution and the Mitochondrial Genome'. Current Opinion in Genetics \& Development 6 (6): 731-36.

TallBear, Kim. 2007. 'Narratives of Race and Indigeneity in the Genographic Project'. Journal of Law, Medicine \& Ethics, no. Genetics and Group Rights (Fall): 412-24.

The International HapMap Consortium. 2003. 'The International HapMap Project'. Nature 426 (December): 789-96. 
Tishkoff, Sarah A., Floyd A. Reed, Françoise R. Friedlaender, Christopher Ehret, Alessia Ranciaro, Alain Froment, Jibril B. Hirbo, et al. 2009. 'The Genetic Structure and History of Africans and African Americans'. Science 324 (5930): 1035-44.

Venter, J. Craig, Mark D. Adams, Eugene W. Myers, Peter W. Li, Richard J. Mural, Granger G. Sutton, Hamilton O. Smith, et al. 2001. 'The Sequence of the Human Genome'. Science 291 (5507): 1304-51. doi:10.1126/science.1058040.

Via, Marc, Christopher R. Gignoux, and Esteban González Burchard. 2010. 'The 1000 Genomes Project: New Opportunities for Research and Social Challenges'. Genome Medicine 2 (1): 3.

Vignal, Alain, Denis Milan, Magali SanCristobal, and André Eggen. 2002. 'A Review on SNP and Other Types of Molecular Markers and Their Use in Animal Genetics'. Genetics Selection Evolution 34 (3): 275-305.

Wade, Lizzie. 2015. 'DNA Reveals History of Buried Slaves'. Science, March 9. http://www.sciencemag.org/news/2015/03/dna-reveals-history-buried-slaves.

Wade, Peter, Carlos López Beltrán, Eduardo Restrepo, and Ricardo Ventura Santos, eds. 2014. Mestizo Genomics: Race Mixture, Nation, and Science in Latin America. Durham and London: Duke University Press.

Washburn, S. L. 1951. 'The New Physical Anthropology'. Transactions of the New York Academy of Sciences, II, 13 (7): 298-304.

Winstein, Keith J. 2007. 'Harvard's Gates Refines Genetic-Ancestry Searches for Blacks'. $\begin{array}{llll}\text { The Wall Street } & \text { Journal, }\end{array}$ http://www.wsj.com/articles/SB119509026198193566.

Winston, Cynthia E., and Rick A. Kittles. 2005. 'Psychological and Ethical Issues Related to Identity and Inferring Ancestry of African Americans'. In Biological Anthropology and Ethics: From Repatriation to Genetic Identity, edited by Trudy R. Turner, 20929. Albany, NY: State University of New York. 